\title{
Eocene flora and trace fossils from the Hruby Regiel section in the Tatra Mountains (Poland): Taxonomic revision of the Wiktor Kuźniar fossil plant collection
}

\author{
GRZEGORZ WOROBIEC ${ }^{1}$, RENATA JACH², ELŻBIETA MACHANIEC ${ }^{2}$, ALFRED UCHMAN ${ }^{2}$ \\ AND ELŻBIETA WOROBIEC ${ }^{1}$ \\ ${ }^{1}$ Department of Palaeobotany, W. Szafer Institute of Botany PAS, Lubicz 46, PL-31-512 Kraków, Poland. \\ E-mails:g.worobiec@botany.pl,e.worobiec@botany.pl \\ ${ }^{2}$ Institute of Geological Sciences, Jagiellonian University, Oleandry 2a, PL-30-063 Kraków, Poland. \\ E-mails:renata.jach@uj.edu.pl,elzbieta.machaniec@uj.edu.pl,alfred.uchman@uj.edu.pl
}

\begin{abstract}
:
Worobiec, G., Jach, R., Machaniec, E., Uchman, A. and Worobiec, E. 2015. Eocene flora and trace fossils from the Hruby Regiel section in the Tatra Mountains (Poland): Taxonomic revision of the Wiktor Kuźniar fossil plant collection. Acta Geologica Polonica, 65 (1), 205-228. Warszawa.
\end{abstract}

\begin{abstract}
Latest Eocene plant macrofossils and trace fossils collected a century ago by Wiktor Kuźniar are revised and their stratigraphical and palaeoecological meaning is re-considered. They derive from marine limestones and marls cropping out on the northern slope of the Hruby Regiel mountain in the Western Tatra Mountains. Leaves belonging to the families Fagaceae and Lauraceae and fruits of the palm Nypa are recognized. The co-occurrence of the planktonic foraminifer taxa Chiloguembelina cf. gracillima and Globigerinatheca $\mathrm{cf}$ index and fruits of Nypa suggests a latest Eocene age of the fossil flora. The plant assemblage is typical of paratropical or subtropical evergreen forests in a warm and humid subtropical climate, recent counterparts of which occur in southeast Asia. The presence of Nypa is characteristic of mangroves. The good state of preservation of the leaves suggests coastline proximity during sedimentation of the plant-bearing deposits.
\end{abstract}

Key words: Fossil leaves; Fossil fruits; Trace fossils; Foraminifera; Biostratigraphy; Palaeoecology; Palaeoclimate; Late Eocene; Western Carpathians.

\section{INTRODUCTION}

The Eocene, an important epoch in the evolution of the biosphere, is characterised by significant changes in the Earth climate. The warm and humid greenhouse climate of the Early and Middle Eocene changed to an icehouse climate through the Late Eocene (Zachos et al. 2001). The climatic deterioration led to dramatic changes in the Eocene flora and fauna and to a significant extinction within some groups of animals and plants (Boulter et al. 1988; Prothero 1994; Sepkoski 1996). During the greenhouse period, land areas of Europe were covered by paratropical rainforest vegetation (Mai 1995; Collinson and Hooker 2003).

Fossil remains of Eocene plants are known from many localities in Europe. One of them is Geiseltal near Halle, Germany, with excellently preserved plants and animals (Mai 1976; Wilde 1995; Mai and Walther 2000). In Poland, Eocene floras are rather scarce, represented mainly by assemblages of plant microfossils 
yielded by borehole cores (Grabowska 1996a). Eocene plant macroremains in Poland are typically found in Baltic amber (Grabowska 1996b; Kosmowska-Ceranowicz 1996). However, amber in Poland is usually redeposited into Quaternary rocks from areas located to the north. Eocene plant macroremains in southern Poland were found in the Carpathians and almost exclusively in the Tatra Mountains. They are represented mostly by plant detritus, in some localities accompanied by remains of fossil leaves and exceptionally also by carpological remains (Głazek and Zastawniak 1999).

The first report on plant macroremains from the
Eocene of the northern slopes of the Tatra Mountains was published by Raciborski (1892). In the "Turek valley" (territory of Slovakia), he found numerous horsetail remains, referred to as Equisetum uhligi Raciborski, accompanied by an oak leaf, some coniferous remains and other poorly preserved leaves (probably Myricaceae and Salicaceae). Kuźniar (1910) described abundant Eocene plant remains from the road-cutting on the northern slope of the Hruby Regiel mountain. This flora comprises almost exclusively impressions of leaves, with rare carpological remains. Szafer (1958) presented a new Eocene plant macroremains assem-

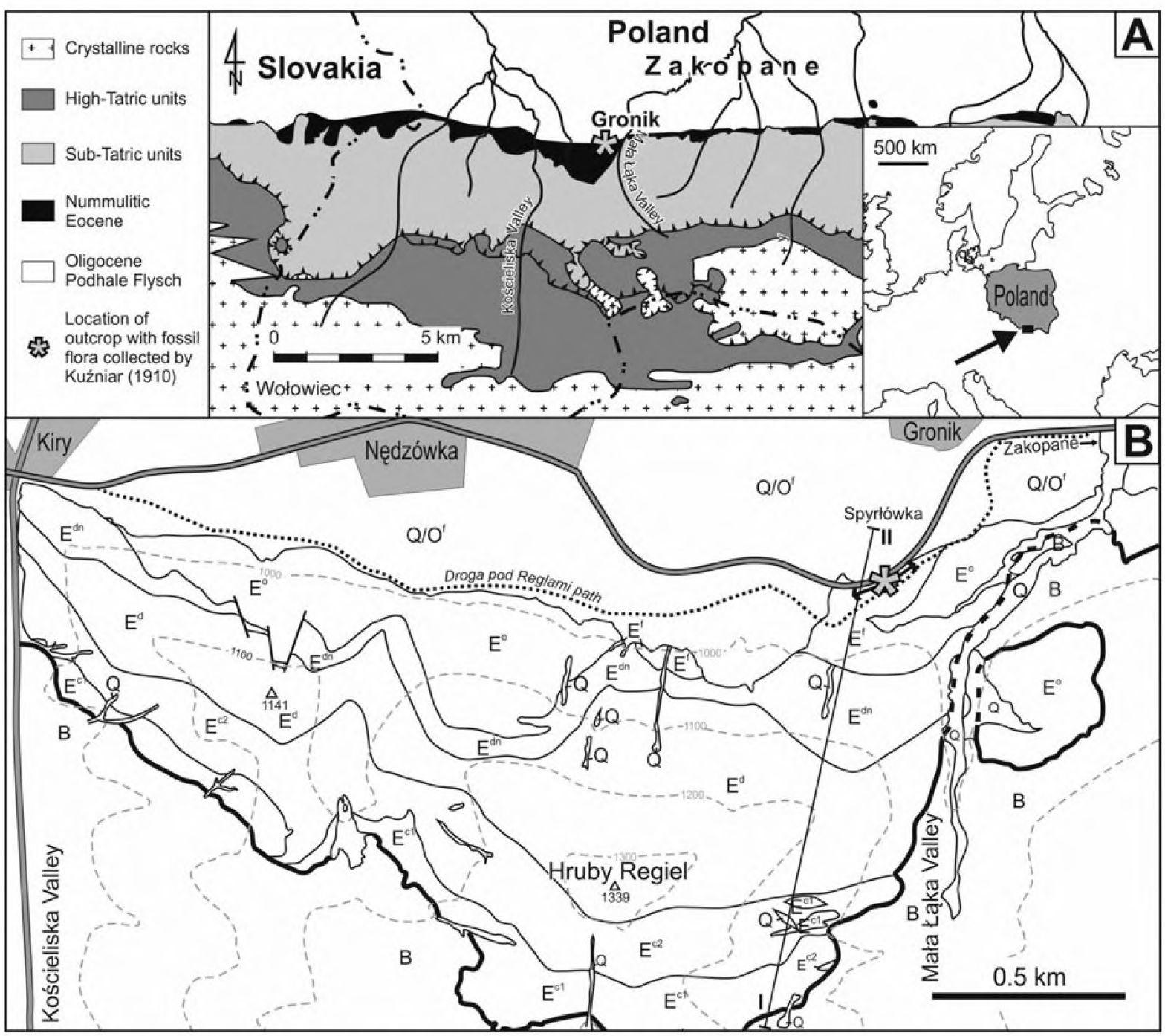

B - Mesozoic basement rocks

$E^{c 1}$ - red conglomerates

$E^{c^{2}}$ - gray conglomerates

$E^{d}$ - detrital dolomites (extraclastic packstones)
$\mathrm{E}^{\mathrm{dn}}$ - detrital dolomitic limestones with nummulites and nummulitic limestones and discocyclinid limestones

$E^{f}$ - plant-bearing sandy limestones and marls
$\mathrm{E}^{\circ}$ - conglomeratic limestones with nummulites, organodetritic limestones, fine-crystalline limestones, dark-brownish limestones, nummulitic limestones with red algea and clasts

$Q / O^{\dagger}$ - debris on flysch deposits

Q - Quaternary sediments

Text-fig. 1. Location maps. A - Geological sketch-map of the Polish part of the Tatra Mountains (after Bac-Moszaszwili et al. 1979, simplified). B - Detailed geological map of the Hruby Regiel Mountain with location of the study area (after Sokolowski 1959, modified) 
blage from the quarry at Chłabówka. It is represented by leaves of Lauraceae (Cinnamomum sp.), Palmae, Myrtaceae, Cornaceae, and probably also Moraceae (Ficus), Myricaceae and Sterculiaceae. Zastawniak (in Passendorfer 1983) briefly revised Szafer's (1958) collection and ascribed these remains to Sabalites, Daphnogene, and presumably to Apocynaceae and Salicaceae. Subsequently, the material was revised by Glazek and Zastawniak (1999), who reported leaf remains of the fern Acrostichum, leaves of Lauraceae (Daphnogene), Araceae, palms (Sabalites) and an extinct member of Fagaceae, Eotrigonobalanus furcinervis Walther et Z. Kvaček. Starczewska-Koziolowa (1961) found some Eocene plant remains in the area of the Krokiew ski jump which were not subsequently investigated. The history of investigations of the Palaeogene plant macrofossils from the Tatra Mountains was summarised by Glazek and Zastawniak (1999).

The current investigation was aimed at a taxonomic revision of the plant macroremains of Kuźniar (1910) from the Eocene of the Hruby Regiel section, some of which appeared to be trace fossils. Most of the original plant determinations were revised and the entire material illustrated for the first time; Kuźniar (1910) did not illustrate his material. The study also revealed the presence of specimens never previously described. The revision enables reinterpretation of the taxonomic composition and palaeoecology of plant assemblages during the Eocene (Priabonian) in the Western Carpathians in relation to the palaeoclimate at that time.

\section{GEOLOGICAL SETTING}

The so-called Tatric or Nummulitic Eocene of the Tatra Mountains forms the lowermost part of the sedimentary succession of the Central Carpathian Palaeogene (Text-fig. 1; Bac-Moszaszwili et al. 1979). These deposits discordantly overlie the Variscan crystalline basement and its autochtonous and allochtonous Permo-Mesozoic sedimentary cover. They represent a transgressive sequence which starts with Lutetian and locally lowermost Bartonian terrigenous and littoral conglomerates composed of bedrock clasts (Text-fig. 2). These deposits are overlain by Lutetian-Bartonian littoral extraclastic carbonates represented by detrital dolomites and detrital dolomitic limestones with nummulites. Locally, in their uppermost part, nummulitic banks with large benthic foraminifera dominated by Nummulites sp. occur (Bieda 1963; Roniewicz 1969; Kulka 1985; Olszewska and Wieczorek 1998; Bartholdy et al. 1999; Jach and Machaniec 2014).

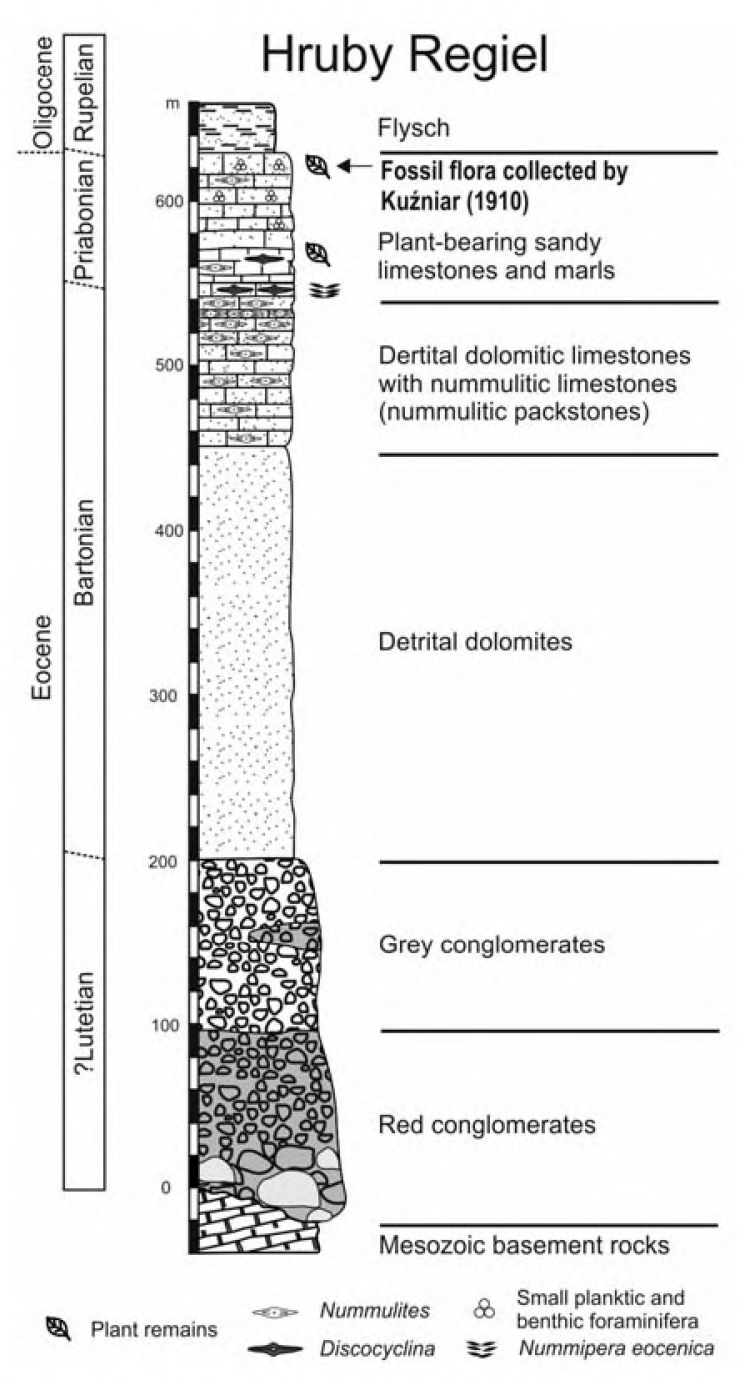

Text-fig. 2. Lithostratigraphical log of Eocene deposits in the Hruby Regiel section, Tatra Mountains (after Sokołowski 1959, modified)

The uppermost Bartonian through Priabonian carbonates are characterized by a distinct facies composition (Bieda 1963; Bartholdy et al. 1995; Machaniec et al. 2011; Jach et al. 2012). They are usually developed as limestones with abundant large benthic foraminifera and red algae, which are locally overlaid with carbonate conglomerates. Laterally, they are replaced with plant-bearing sandy limestones and marls. The latter, well-developed in the Hruby Regiel area, are about $70 \mathrm{~m}$ thick. These deposits were previously referred to as the "sandy limestones with fucoids" (Kuźniar 1910), "floral beds" (Sokołowski 1959) or "sandy limestones and shales with flora" (Guzik et al. 1958). In this area, the facies distribution was controlled by synsedimentary tectonics (Jach et al. 2009, 2012; Dąbrowska and Jurewicz 2013). The carbonates 

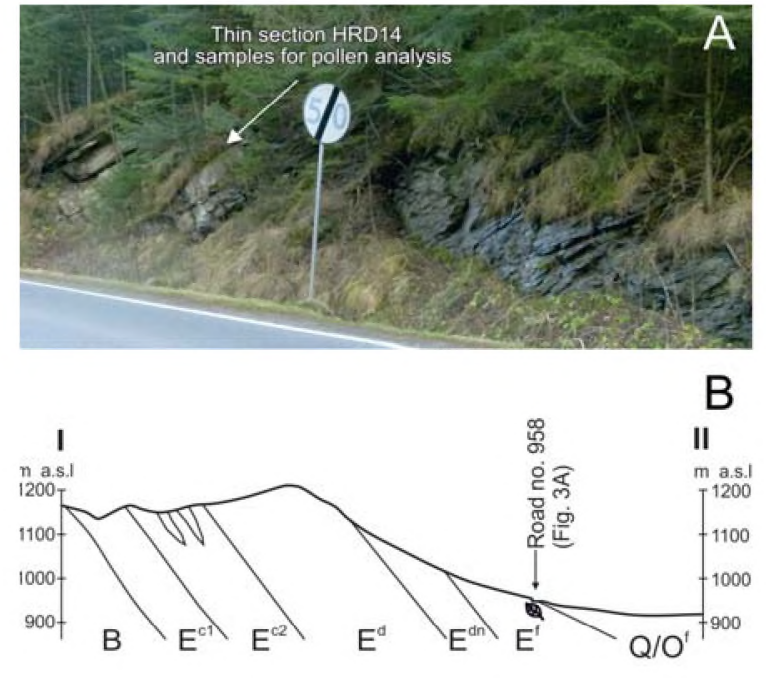

Text-fig. 3. Hruby Regiel section. A - View of the rock cliff with plant-bearing sandy limestones and marls, outcrop along the Zakopane-Witów road; B - Cross section I-II of the Hruby Regiel eastern slope as shown in Text-fig. 1 (after Sokołowski 1959, modified)
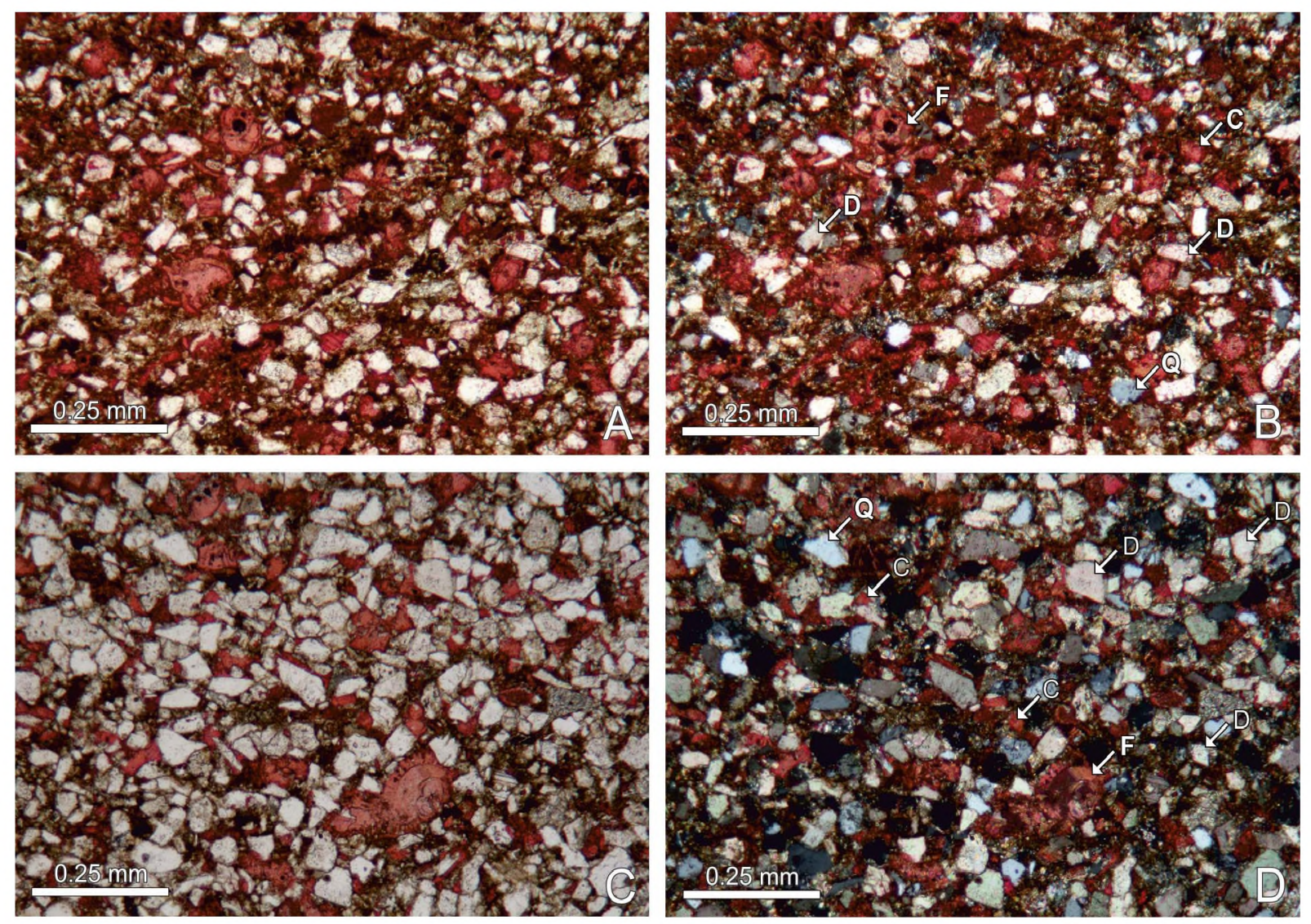

Text-fig. 4. Microfacies of plant-bearing sandy limestones and marls of Hruby Regiel section. Thin sections are stained with alizarin red S and ferricyanide potassium solution. Symbols: Q - quartz, D - dolomite, C - calcite, F -foraminifera. A - extraclastic packstone composed of sharp-edged dolomite grains, angular or moderately rounded quartz and calcitic bioclasts; sample HRD14, plane polarised light; B - sample HRD14, cross polarised light; C - extraclastic packstone composed of sharp-edged dolomite grains, angular or moderately rounded quartz and calcitic bioclasts mainly of foraminifera tests; sample 24/2013, plane polarised light; 
EOCENE FLORA FROM THE TATRA MOUNTAINS, POLAND

\section{MATERIALS AND METHODS}

The collection of Wiktor Kuźniar is stored in the Museum of the Institute of Geological Sciences, Polish Academy of Sciences, Kraków. Unfortunately, Kuźniar (1910) did not put numbers directly on his specimens. In consequence, the loose labels accompanying the specimens are mixed and partially lost. Some of the specimens were added later by an unknown collector, as indicated by the label of one the specimens, with the note "1928". Barbara KietlińskaMichalik (the Museum of the Institute of Geological Sciences, Polish Academy of Sciences, Kraków) found some previously uncatalogued and lost specimens from the collection. Most of the specimens were catalogued later and the catalogue prefix A-III-61 with the specimen number was added for each specimen. In total, the collection is composed of 50 specimens. All of them are re-catalogued here (No. 2013/1-50).

The plant macroremains (mainly leaves) are preserved mostly as impressions, one cast, and some coalified plant detritus, all in fine-grained limestones and marls. The state of preservation of the remains is usually good. However, the impressions of the network of the leaf venation are generally poorly preserved and only impressions of primary and some secondary veins are visible. The plant fossils were identified solely on the basis of macromorphology. Leaf descriptions follow mostly Ellis et al. (2009). The drawings were made under a Carl Zeiss stereomicroscope with a camera lucida attachment. Macrophotographs were taken using an Olympus E-PL1 digital camera.

Two samples for pollen analysis were taken from the outcrop (Text-fig. 3A). The material was processed in the laboratory of the W. Szafer Institute of Botany, Polish Academy of Sciences, Kraków. Each sample was divided into two parts. One part of the material was processed according to the modified Erdtman's acetolysis method (Moore et al. 1991), using hydrofluoric acid to remove mineral matter; and the second part was processed using heavy liquid $\left(\mathrm{ZnCl}_{2}+\mathrm{HCl}\right.$; density $2.2 \mathrm{~g} / \mathrm{cm}^{3}$ ). Additionally, half of the material from each sample was sieved at $5 \mu \mathrm{m}$ on a nylon mesh. The microscope slides were made using glycerine as a mounting medium. The rock samples and palynological residues are stored in the W. Szafer Institute of Botany, Polish Academy of Sciences, Kraków. Both samples contained no sporomorphs. However, they were full of organic particles (sedimentary organic matter) allowing analysis of the palynological matter. Description of the sedimentary organic matter follows Tyson $(1993,1995)$ and Batten (1996). Microphotographs of palynofacies were taken using a NIKON Eclipse microscope fitted with a Canon digital camera.

Microfacies as well as the foraminifera were studied in thin sections [two thin sections from a sample collected by Kuźniar (1910; sample 24/2013) and 10 thin sections from the outcrop] under Carl Zeiss Axioskop and Nikon Eclipse E600 POL optical microscopes and a Nikon SMZ 1500 stereo microscope. Thin sections are stored at the Institute of Geological Sciences, Jagiellonian University in Kraków.

\section{SYSTEMATIC PALAEOBOTANY}

The classification of higher taxonomic categories follows Reveal (1996) and Takhtajan (2009) and author names of families follow APG III (2009).

Division: Magnoliophyta (Angiosperms) Cronquist, Takhtajan et Zimmermann ex Reveal 1996

Class: Magnoliopsida (Dicotyledons) Brongniart 1843

Family Lauraceae Jussieu 1789

Genus Daphnogene Unger 1845

cf. Daphnogene sp.

(Text-fig. 5A)

1910. Daphnogene melastomacea? Unger; Kuźniar, p. 46.

MATERIAL: 8/2013 (A-III-61/5).

DESCRIPTION: One leaf, about $5 \mathrm{~cm}$ long and $4 \mathrm{~cm}$ wide, entire-margined, slightly asymmetric. Venation pinnate, secondary venation acrodromous.

REMARKS: The characteristic venation of the leaf remains allowed their identification as the fossil-taxon Daphnogene (synonym of Cinnamomophyllum and Cinnamomum). The generic name Daphnogene Unger is an artificial name given to fossil leaves from the family Lauraceae with acrodromous venation (triplinerved), similar to the recent genus Cinnamomum Schaeffer (Kvaček and Knobloch 1967; Mai and Walther 1978). In the opinion of Kvaček (1971), it is impossible to assign fossil leaf taxa of the family Lauraceae to an extant genus on the basis of either the morphology or the anatomy.

MODERN EQUIVALENTS: In respect of morphology, fossil leaves of Daphnogene could be compared to leaves of several extant genera of the Lauraceae, in- 

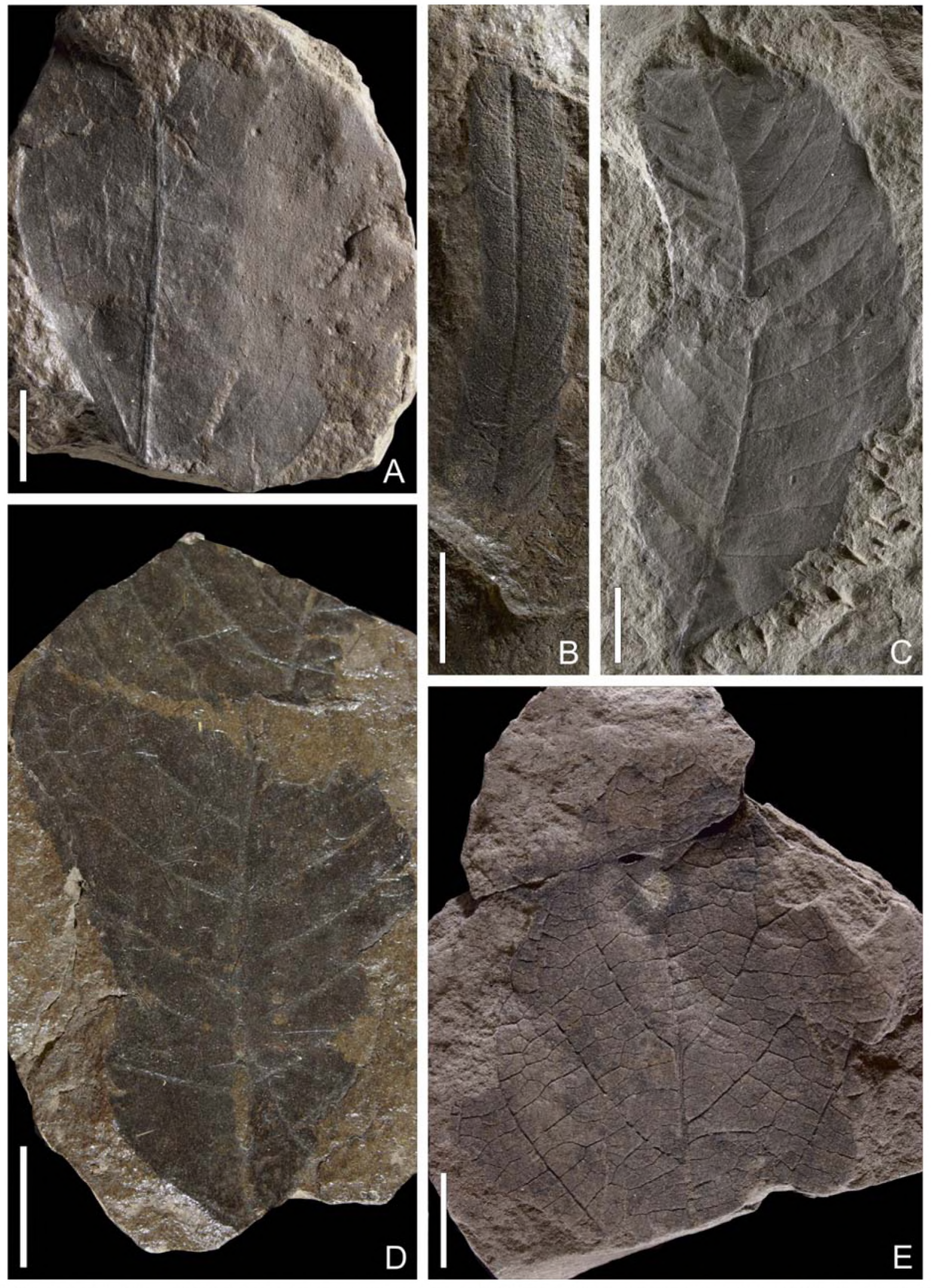

Text-fig. 5. Fossil plants from the Wiktor Kuźniar collection. A - cf. Daphnogene sp. (8/2013); B-D - Eotrigonobalanus furcinervis (Rossmässler) Walther et Z. Kvaček ssp. furcinervis 1989 (B: 19/2013, C: 42/2013, D: 7/2013): E - Dicotylophyllum cf. juglandoides (Rossmässler) Knobloch et Z. Kvaček 1996 (48/2013). Scale bar - 1 cm 
cluding Cryptocarya, Litsea, Lindera, and Neolitsea (Kolakovskii 1958; Kvaček 1971). Acrodromous venation occurs in at least 11 genera of the family Lauraceae (Bannister et al. 2012).

ECOLOGY: Daphnogene represents a palaeotropical element and was a component of mesophytic and swamp vegetation.

OCCURRENCE: Leaves of Daphnogene are common in the fossil leaf assemblages of warm periods of the Palaeogene and Neogene of Europe (Mai 1995). In the territory of Poland, they are reported from Eocene and Miocene floras (Worobiec 2007).

Family Fagaceae Dumortier 1829

Genus Eotrigonobalanus Walther et Z. Kvaček 1989

Eotrigonobalanus furcinervis (Rossmässler) Walther

et Z. Kvaček ssp. furcinervis 1989

[cf. Eotrigonobalanus furcinervis (Rossmässler)

Walther et Z. Kvaček 1989]

(Text-figs 5B-D, 6A)

1840. Phyllites furcinervis Rossmässler, p. 33-34, pl. 6, fig. 25 , pl. 7, figs 32-36.

1910. Carpinus grandis Unger; Kuźniar, p. 43

1989. Eotrigonobalanus furcinervis (Rossmässler); Walther et Z. Kvaček ssp. furcinervis, p. 583, figs 3-5, pl. 33, figs 1-6, pl. 38, fig. 3, pl. 39, fig. 1, pl. 40, figs 1-5, pl. 41 , figs $1-4$, pl. 42 , figs $1-4$, pl. 43 , figs $1-6$.

MATERIAL: 7/2013 (A-III-61/17), 19/2013 (A-III61/6), 42/2013 (A-III-61/29), 2/2013 (cf. Eotrigonobalanus furcinervis).
DESCRIPTION: Leaf fragments, up to $7.6 \mathrm{~cm}$ long and 2-4 cm wide, one specimen with obtuse leaf base. Leaves both serrate and entire-margined, especially in basal part. Secondary veins and their branches terminate at tooth apex. Venation pinnate, primary vein straight or bent, usually rather thick. Secondary venation mixed: craspedodromous in serrate part of leaves and brochidodromous in entire-margined part. Up to 13 pairs of secondary veins are preserved. Secondaries curved upward, at intervals of $0.4-0.6 \mathrm{~cm}$. Secondary veins form an angle of $50-70^{\circ}$ with the primary vein.

REMARKS: Extinct member of the family Fagaceae. Serrate leaves are typical of this subspecies. A leaf of ?Eotrigonobalanus furcinervis was earlier reported from the Upper Eocene deposits of Chłabówka (Głazek and Zastawniak 1999). Kuźniar (1910) also probably reported it mistakenly as Dryandroides angustifolia? Unger and Quercus urophylla Unger. It was not possible to find Kuźniar's (1910) taxonomic determinations of specimens $2 / 2013,7 / 2013$, and 19/2013.

MODERN EQUIVALENTS: Fossil-taxon related to recent members of the fagaceous genera Castanopsis, Litocarpus and Trigonobalanus (Denk et al. 2012).

ECOLOGY: Eotrigonobalanus furcinervis represents a palaeotropical element. This taxon was an important component of the European Palaeogene mesophytic to swamp forest vegetation (Mai 1995; Uhl et al. 2002; Denk et al. 2012; Hennig and Kunzmann 2013).

OCCURRENCE: Eotrigonobalanus furcinervis is reported from the Middle Eocene to Lower Miocene deposits of Europe (Mai 1995; Uhl et al. 2002; Denk et al. 2012; Hennig and Kunzmann 2013).
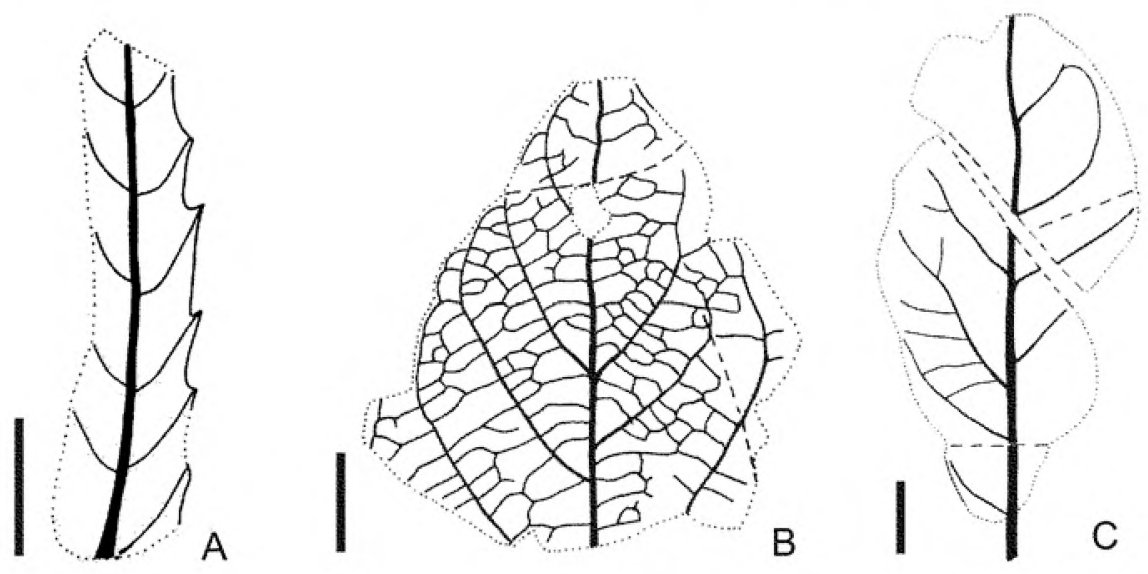

Text-fig. 6. Fossil plants from the Wiktor Kuźniar collection. A-Eotrigonobalanus furcinervis (Rossmässler) Walther et Z. Kvaček ssp. furcinervis 1989 (19/2013); B - Dicotylophyllum cf. juglandoides (Rossmässler) Knobloch et Z. Kvaček 1996 (48/2013); C - Dicotylophyllum sp. 5 (47/2013). Scale bar - $1 \mathrm{~cm}$ 
Dicotyledones incertae sedis

Genus Dicotylophyllum Saporta 1894

Dicotylophyllum $\mathrm{cf}$. juglandoides (Rossmässler)

Knobloch et Z. Kvaček 1996

(Text-figs 5E, 6B)

? 1840. Phyllites juglandoides Rossmässler, p. 29-30, pl. 4, fig. 16.

? 1996. Dicotylophyllum juglandoides (Rossmässler) Knobloch et Z. Kvaček; Knobloch et al., p. 108-111, figs $53 \mathrm{a}-\mathrm{e}, 54 \mathrm{a}-\mathrm{c}, 55 \mathrm{a}-\mathrm{c}, \mathrm{pl}$. 14, figs $2-3$, pl. 20, figs $1-4$, pl. 21, figs $1-3$.

MATERIAL: 48/2013 (A-III-61/18).

DESCRIPTION: Leaf fragment, about $5 \mathrm{~cm}$ long and $5 \mathrm{~cm}$ wide, entire-margined. Venation pinnate, primary vein straight, of moderate thickness. Secondary venation brochidodromous. Secondaries curved upward and interconnected in loops, distributed at intervals of $0.7-1.2 \mathrm{~cm}$. Secondary veins form an angle of $40-50^{\circ}$ with the primary vein. Tertiary venation distinctly percurrent. About 5 tertiary veins occur per 1 $\mathrm{cm}$ of secondary vein length. Higher-order venation reticulate.

REMARKS: The leaf shape and architecture of the leaf venation are similar to those in the fossil-species $D i$ cotylophyllum juglandoides (Rossmässler) Knobloch et Z. Kvaček, a new combination erected on the basis of the Eocene leaf material from the locality Staré Sedlo in Czech Republic (Knobloch et al. 1996). It was not possible to find Kuźniar's (1910) taxonomic determination of this specimen.

MODERN EQUIVALENTS: Rossmässler (1840) compared discussed fossil with leaves of the Recent genera Magnolia, Tetranthera, Persea and Visnea.

\section{Dicotylophyllum sp. 1}

(Text-fig. 7A)

1910. Eucaliptus oceanica Unger; Kuźniar, p. 48-49.

MATERIAL: 6/2013 (A-III-61/32), 11/2013 (A-III61/24).

DESCRIPTION: Leaf fragments, (specimen 11/2013: $6.6 \mathrm{~cm}$ long and $1.2 \mathrm{~cm}$ wide), entire-margined. Venation pinnate, primary vein straight, thick. Secondary veins curved upward.
REMARKS: The systematic position of these leaf fossil fragments remains unknown due to the absence of distinctive features and the poor state of preservation. The second specimen of Dicotylophyllum sp. 1, found in the collection of plant remains from Hruby Regiel and labelled "Edocarpus eocenica Unger", was not mentioned in the paper of Kuźniar (1910).

\section{Dicotylophyllum sp. 2}

(Text-fig. 7B)

MATERIAL: 18/2013 (A-III-61/21).

DESCRIPTION: Fragment of large leaf, about $13 \mathrm{~cm}$ long and $8 \mathrm{~cm}$ wide, entire-margined. Venation pinnate, primary vein straight, rather thick. Secondary veins distributed at intervals of about $2.5 \mathrm{~cm}$, forming an angle of $40-50^{\circ}$ with the primary vein.

REMARKS: The systematic position of this leaf fossil fragment remains unknown due to the absence of distinctive features and the poor state of preservation. It was not possible to find Kuźniar's (1910) taxonomic determination of this specimen.

\section{Dicotylophyllum sp. 3 \\ (Text-fig. 7C)}

\section{MATERIAL: 27/2013 (A-III-61/25).}

DESCRIPTION: Fragment of probably coriaceous leaf, $5.2 \mathrm{~cm}$ long and $1.7 \mathrm{~cm}$ wide, entire-margined. Venation pinnate, primary vein straight, moderate thickness. Secondary venation brochidodromous. Secondary veins distributed at intervals of $0.7-1.1 \mathrm{~cm}$, forming an angle of about $40^{\circ}$ with the primary vein.

REMARKS: The systematic position of this leaf fossil fragment remains unknown due to the absence of distinctive features and the poor state of preservation. The specimen, found in the collection of plant remains from Hruby Regiel with the label "Quercus daena Heer", was not mentioned in the paper of Kuźniar (1910).

\section{Dicotylophyllum sp. 4 \\ (Text-fig. 7D)}

1910. Populus mutabilis repando-crenata Heer; Kuźniar, p. 44-45. 
EOCENE FLORA FROM THE TATRA MOUNTAINS, POLAND
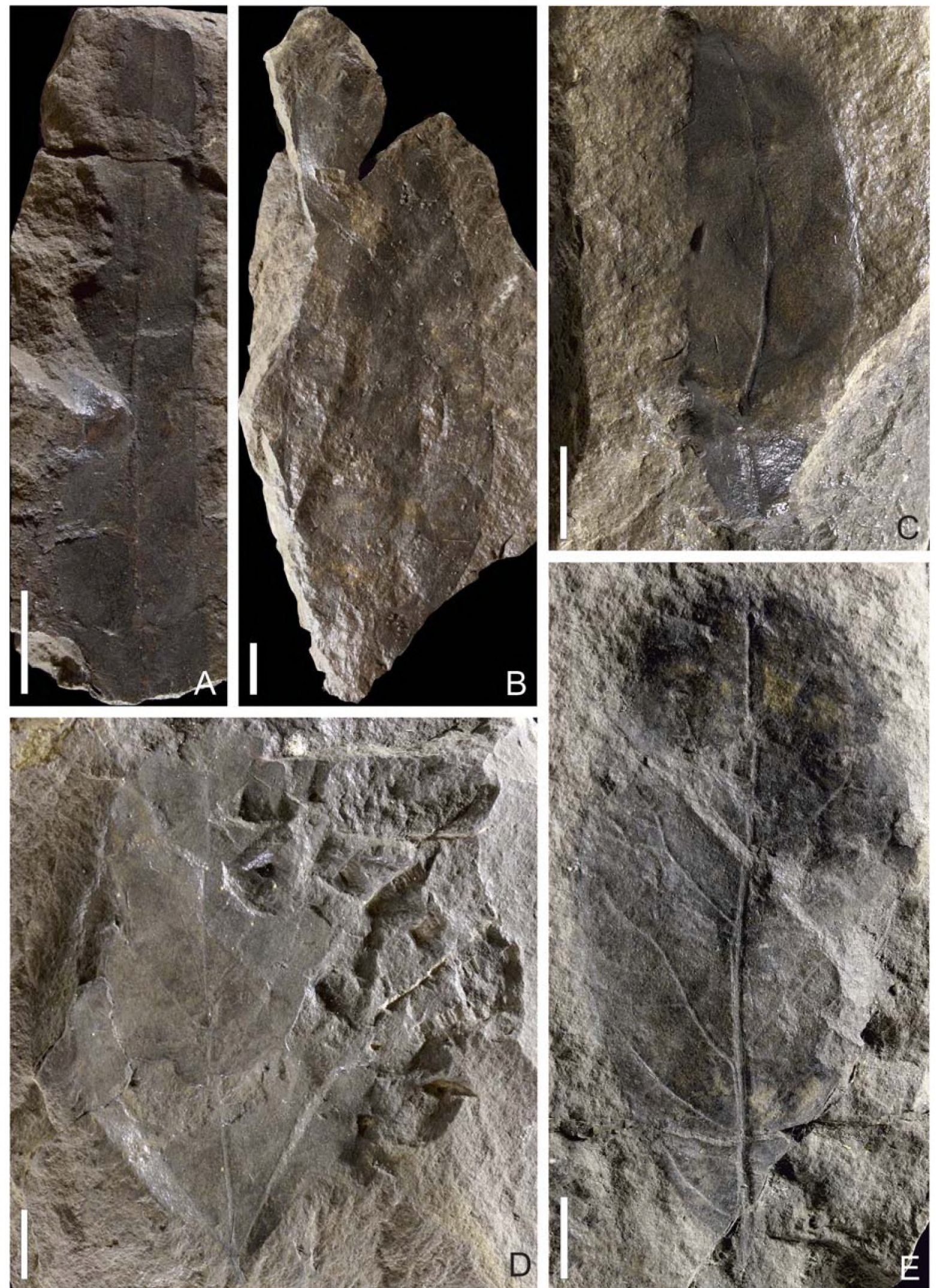

Text-fig. 7. Fossil plants from the Wiktor Kuźniar collection. A - Dicotylophyllum sp. 1 (11/2013); B - Dicotylophyllum sp. 2 (18/2013); C - Dicotylophyllum sp. 3 (27/2013); D - Dicotylophylhum sp. 4 (33/2013); E - Dicotylophyllum sp. 5 (47/2013). Scale bar - $1 \mathrm{~cm}$ 
MATERIAL: 33/2013 (A-III-61/30), 34/2013 (A-III61/14), 45/2013.

DESCRIPTION: Fragments of entire-margined leaves. Preserved leaf base more or less obtuse. Venation imperfectly acrodromous. Secondary veins form an angle of $50-60^{\circ}$ with the midvein.

REMARKS: The systematic position of these leaf fossil fragments remains unknown due to the absence of distinctive features and the poor state of preservation. It was not possible to find Kuźniar's (1910) taxonomic determination of specimens 34/2013 and 45/2013.

\section{Dicotylophyllum sp. 5 \\ (Text-figs 6C, 7E)}

1910. Pyrus troglodytarum Unger; Kuźniar, p. 49.

MATERIAL: 47/2013 (A-III-61/31).

DESCRIPTION: Fragment of entire-margined leaf, with obtuse leaf base. Venation pinnate, primary vein thick. Secondary venation camptodromous. Secondaries curved slightly upward and branched, distributed at intervals of $0.9-1.6 \mathrm{~cm}$. Secondary veins form an angle of $40-55^{\circ}$ with the primary vein.

REMARKS: The systematic position of this leaf fossil fragment remains unknown due to the absence of distinctive features and the poor state of preservation.

\section{Dicotylophyllum sp. 6}

(Text-fig. 8A)

1910. Apocynophyllum lanceolatum Unger; Kuźniar, p. 47.

MATERIAL: 36/2013 (A-III-61/33).

DESCRIPTION: Large coriaceous leaf, $17 \mathrm{~cm}$ long and $5 \mathrm{~cm}$ wide, entire-margined, margin revolute. Venation pinnate, secondary venation camptodromous. Secondaries curved slightly upward, distributed at intervals of about $1-2 \mathrm{~cm}$. Secondary veins form an angle of about $50^{\circ}$ with the primary vein.

REMARKS: The systematic position of this leaf fossil remains unknown due to the absence of distinctive features and the poor state of preservation
Dicotyledones incertae sedis $=$ Dicotyledones indet. (Text-fig. 8B, C)

1910. Daphnogene melastomacea Unger; Kuźniar, pro parte, p. 46 [only 30/2013].

1910. Ficus morloti Unger; Kuźniar, p. 44.

1910. Laurus lalages Unger; Kuźniar, pro parte, p. 45 [only 26/2013 and 28/2013].

MATERIAL: 5/2013, 17/2013 (A-III-61/26), 20/2013 (A-III-61/8), 21/2013, 22/2013, 24/2013, 25/2013 (AIII-61/19), 26/2013 (A-III-61/28), 28/2013, 30/2013 (A-III-61/10), 31/2013 (A-III-61/9), 32/2013 (A-III61/13), 35/2013 (A-III-61/1), 40/2013 (A-III-61/7), 41/2013 (A-III-61/12), 43/2013 (A-III-61/11), 44/2013 (A-III-61/2).

REMARKS: The systematic position of these plant remains is unknown. Specimen found in collection from Hruby Regiel with the label "Quercus chlorophylla Unger", was not mentioned in Kuźniar (1910). It was not possible to find Kuźniar's (1910) taxonomic determination of specimens 20/2013,21/2013, 22/2013, 24/2013, 25/2013, 31/2013, and 32/2013.

Class: Liliopsida (Monocotyledons)

Family: Arecaceae Bercht. et Pres1. 1820 Genus Nypa Steck 1757

Nypa burtini (Brongniart) Ettingshausen 1879

(Text-fig. 8E, F)

1828. Cocos burtini; Brongniart, p. 121.

1849. Nipadites burtini; Brongniart, p. 88.

1879. Nipa burtini Brongniart; Ettingshausen, p. 393.

1910. Nipadites burtini Brongniart; Kuźniar, p. 40-41.

MATERIAL: 15/2013 (A-III-61/34), 38/2013 (A-III-61/3).

DESCRIPTION: Two remains: impression and strongly compressed cast of fruit. Cast: $12.5 \mathrm{~cm}$ long, $8 \mathrm{~cm}$ wide, obovoid, with traces of longitudinal ridges and deformed umbo (about $2.3 \mathrm{~cm}$ in size). Impression: about $10 \mathrm{~cm}$ long and $11 \mathrm{~cm}$ wide, suborbicular, surface of impression with numerous impressions of longitudinal ridges.

REMARKS: The morphology of the remains, especially the obovoid shape and longitudinal ridges suggest an affinity with the genus Nypa. Fossil carpological remains comparable to $N y p a$, have been described under the genera Burtinia, Castellinia, Fracastoria, Nipa, Nipadites, and Nypa (Tralau 1964). 
EOCENE FLORA FROM THE TATRA MOUNTAINS, POLAND
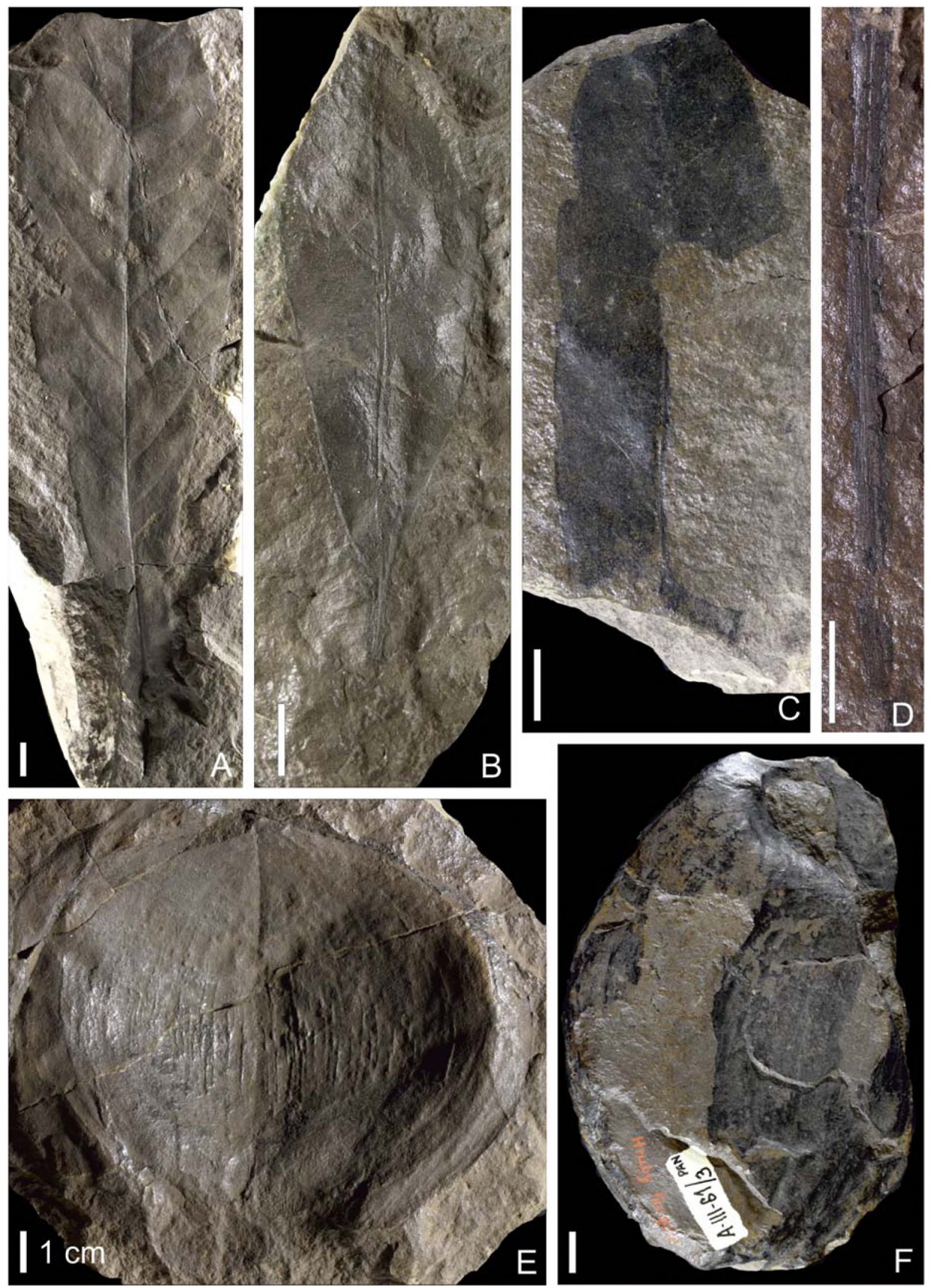

Text-fig. 8. Fossil plants from the Wiktor Kuźniar collection. A-Dicotylophyllum sp. 6 (36/2013); B, C-Dicotyledones incertae sedis = Dicotyledones indet. (B: 28/2013, C: 30/2013); D - Incertae sedis (11/2013); E, F - Nypa burtini (Brongniart) Ettingshausen 1879 (E: fruit impression, 15/2013, F: fruit cast, 38/2013). Scale bar $-1 \mathrm{~cm}$ 
MODERN EQUIVALENTS: Today, Nypa is a monotypic genus, with the species $N$. fruticans Wurmb., which is restricted to the tropical coast of southeast Asia and growing mostly in mangrove communities in a tropical, frost-free climate (Krutzsch 1989). Nypa burtini differs from the extant $N$. fruticans in seed morphology and anatomy, which is discussed broadly by El-Soughier et al. (2011).

ECOLOGY: Nypa represents a palaeotropical element. This taxon was a component of mangrove vegetation (Tsuji et al. 2011).

OCCURRENCE: Nypa is known from the beginning of the Cretaceous. In Europe it was common in Eocene floras (Belgium, France, Hungary, Poland, Spain, Ukraine, United Kingdom) and disappeared in the latest Eocene. Outside Europe, it was reported from the Late Cretaceous to Palaeocene of South America (Brazil, Colombia, Venezuela), the Eocene of North America, the Late Cretaceous to Middle Eocene of Africa (Cameroon, Egypt, Nigeria) and from the Late Cretaceous to Recent in many localities in southeast Asia and Australia (Krutzsch 1989; Gee 1990; Gray 1993; Gee 2001; Plaziat et al. 2001).

Incertae sedis

(Text-fig. 8D)

1910. Quercus sp.; Kuźniar, p. 43.

1910. Poacites sp.; Kuźniar, p. 40.

MATERIAL: $1 / 2013,3 / 2013,4 / 2013$ (A-III-61/27 and A-III-61/24), 4/2013, 9/2013, 12/2013 (A-III-61/20), 16/2013, 23/2013, 29/2013, 37/2013, 39/2013, 46/2013, 49/2013 (A-III-61/15), 50/2013 (A-III$61 / 22)$.

REMARKS: Remains of uncertain origin. It was not possible to find Kuźniar's (1910) taxonomic determinations of specimens $1 / 2013,4 / 2013,10 / 2013$, $12 / 2013,13 / 2013,16 / 2013,23 / 2013,29 / 2013$, $37 / 2013,39 / 2013,46 / 2013,49 / 2013,50 / 2013$, and 14/2013.

\section{TRACE FOSSILS}

Three specimens from the studied collection appeared to be trace fossils. Their original labels are missing. Moreover, small cylindrical burrows co-occur with leaves in a few specimens. The interpretation of trace fossils as plants was common throughout the 19th century and continued by some researchers at the beginning of 20th century (Baucon et al. 2012).

\section{Ichnogenus Gyrolithes Saporta, 1884 \\ ?Gyrolithes isp.}

(Text-fig. 9A, B)

MATERIAL: 10/2013.

DESCRIPTION: Fragments of horizontal to subhorizontal, arcuate, endichnial cylinders, $10-12 \mathrm{~mm}$ wide, elliptical in cross section, displaying a thin, knobby wall. The knobs, seen from the interior, are small, circular depressions, $0.5-1 \mathrm{~mm}$ wide, located $1-2 \mathrm{~mm}$ apart. Filling of the cylinders is the same as in the surrounding rock. The cylinders occur on the lower and upper surfaces and inside the specimen, which is a small, $32 \mathrm{~mm}$ thick slab. Their arrangement suggests a vertical, helical spiral pattern. The estimated whorl radius of the spiral can range from 15 to $40 \mathrm{~mm}$ for individual arcs.

REMARKS: The helical, vertical spiral is typical of Gyrolithes Saporta, 1884, however the fragmentary preservation of the described specimen does not allow its unequivocal determination. The knobby wall is known from Gyrolithes marylandicus (Mansfield, 1927) and Gyrolithes nodosus Mayoral and Muñiz, 1998, but the morphometric parameters (burrow width, whorl radius) does not fit these ichnospecies (see Uchman and Hanken 2013), being rather similar to those of the smooth-walled $G$. saxonicus (Häntzschel, 1934) or G. cycloides (Mikuláš and Pek, 1994). Larger Gyrolithes are burrows produced by crustaceans since the Permian (Uchman and Hanken 2013). Their monodominant ichnoassemblages are typical of brackish, shallow-marine deposits (e.g. Netto et al. 2007).

\author{
Ichnogenus Ophiomorpha Lundgren, 1891 \\ Ophiomorpha isp. \\ (Text-fig. 9C)
}

MATERIAL: 13/2013.

DESCRIPTION: This trace fossil is preserved as a fragment of a horizontal to subhorizontal (toponomy of the specimen is unclear), endichnial cylinder, 11-13 $\mathrm{mm}$ in diameter, $145 \mathrm{~mm}$ long, circular in cross section, curved in a gentle arc. It displays a thin, knobby wall. 

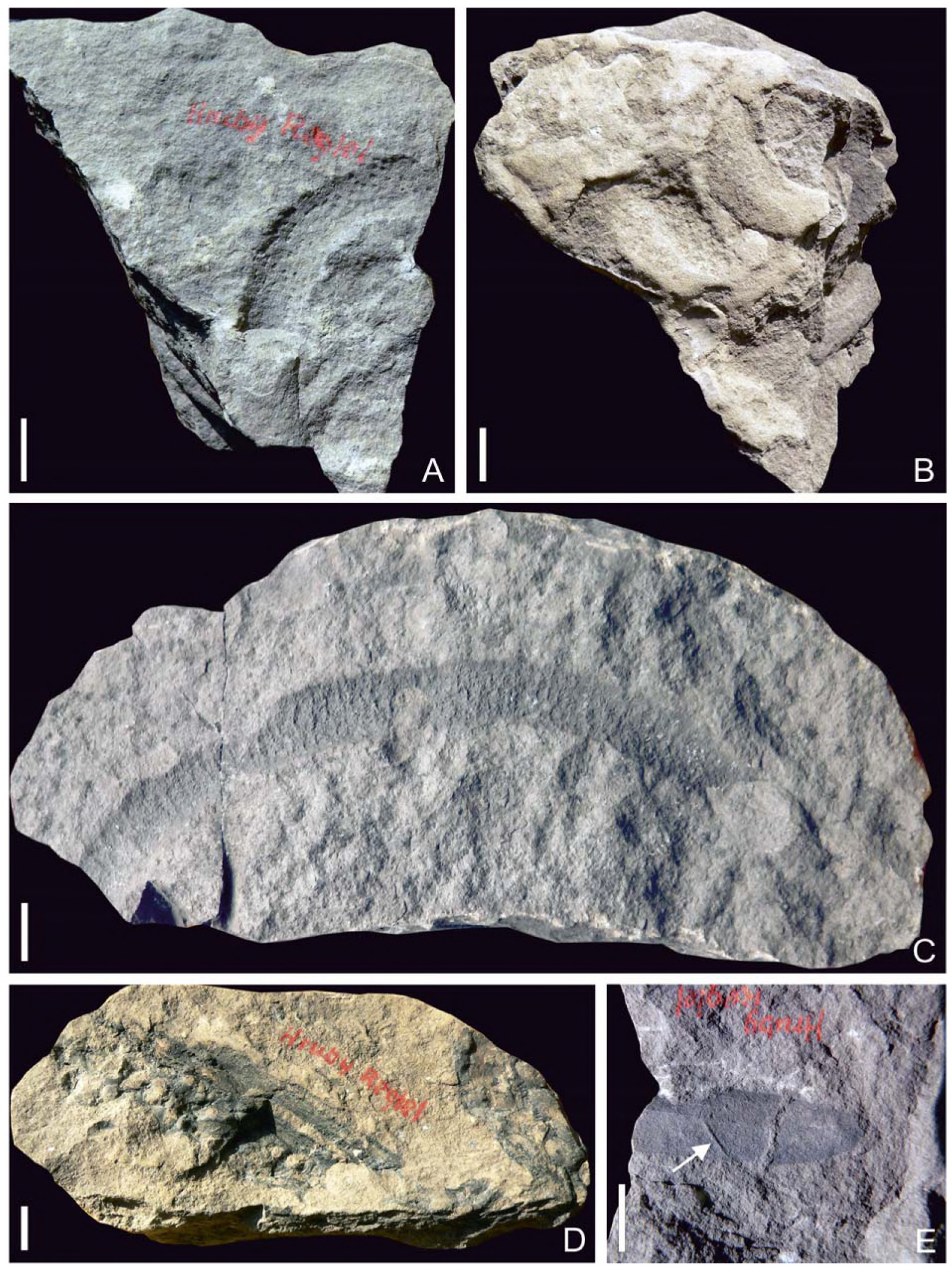

Text-fig. 9. Trace fossils. A, B - ? Gyrolithes isp. (10/2013), view from opposite surfaces; C-Ophiomorpha isp. (13/2013); D - Teredolites clavatus (14/2013); E-small cylindrical burrows (arrow) (32/2013) 
The knobs, seen from the interior, are small, shallow, elliptical depressions, $2.5-3 \mathrm{~mm}$ long, $1-1.5 \mathrm{~mm}$ wide, the longer axes being perpendicular to the course of the cylinder. The knobs are arranged in rings. Filling of the cylinder is the same as in the surrounding rock.

REMARKS: The knobs in the wall, interpreted as agglutinated pellets, are typical of Ophiomorpha Lundgren, 1891. The perpendicular arrangement of the pellets and the diameter of the burrow are similar to Ophiomorpha annulata Książkiewicz, 1977 sensu Howard and Frey (1984) and Frey and Howard (1985), described from the Upper Cretaceous of the United States. However, the type material of Ophiomorpha annulata Książkiewicz, 1977 is different, showing mostly straight, commonly smooth, branched cylinders (Uchman 1995, 1998). Ophiomorpha is a crustacean, mostly decapod burrow, of which the type ichnospecies $O$. nodosa Lundgren, 1891 occurs mostly in shallow-marine sediments (Frey et al. 1978), while Ophiomorpha annulata Książkiewicz, 1977 is typical of flysch deposits (Uchman 1995, 1998).

\section{Ichnogenus Teredolites Leymerie, 1842 Teredolites clavatus Leymerie, 1842}

(Text-fig. 9D)
MATERIAL: 14/2013.

DESCRIPTION: Teredolites clavatus is visible as gregarious, tightly spaced clavate mounds in carbonized woody substrate, 2-6 $\mathrm{mm}$ in diameter, circular to irregularly oval in outline, showing sharp boundaries. Their length is difficult to estimate, because they are observed in cross section and many mounds are truncated by the specimen surface. They are perpendicular to oblique to the grain of the woody substrate. Some individual mounds are in contact with a mutual deformational adjustment.

REMARKS: Teredolites is a boring produced in woody (xylic) substrates (e.g. Kelly and Bromley 1984) by bivalves (Röder 1977) worldwide in shallow- to deepmarine environments (Kelly 1988). Recently, similar borings are produced by Martesia and in the fossil record by Martesia and Opertochasma. T. clavatus
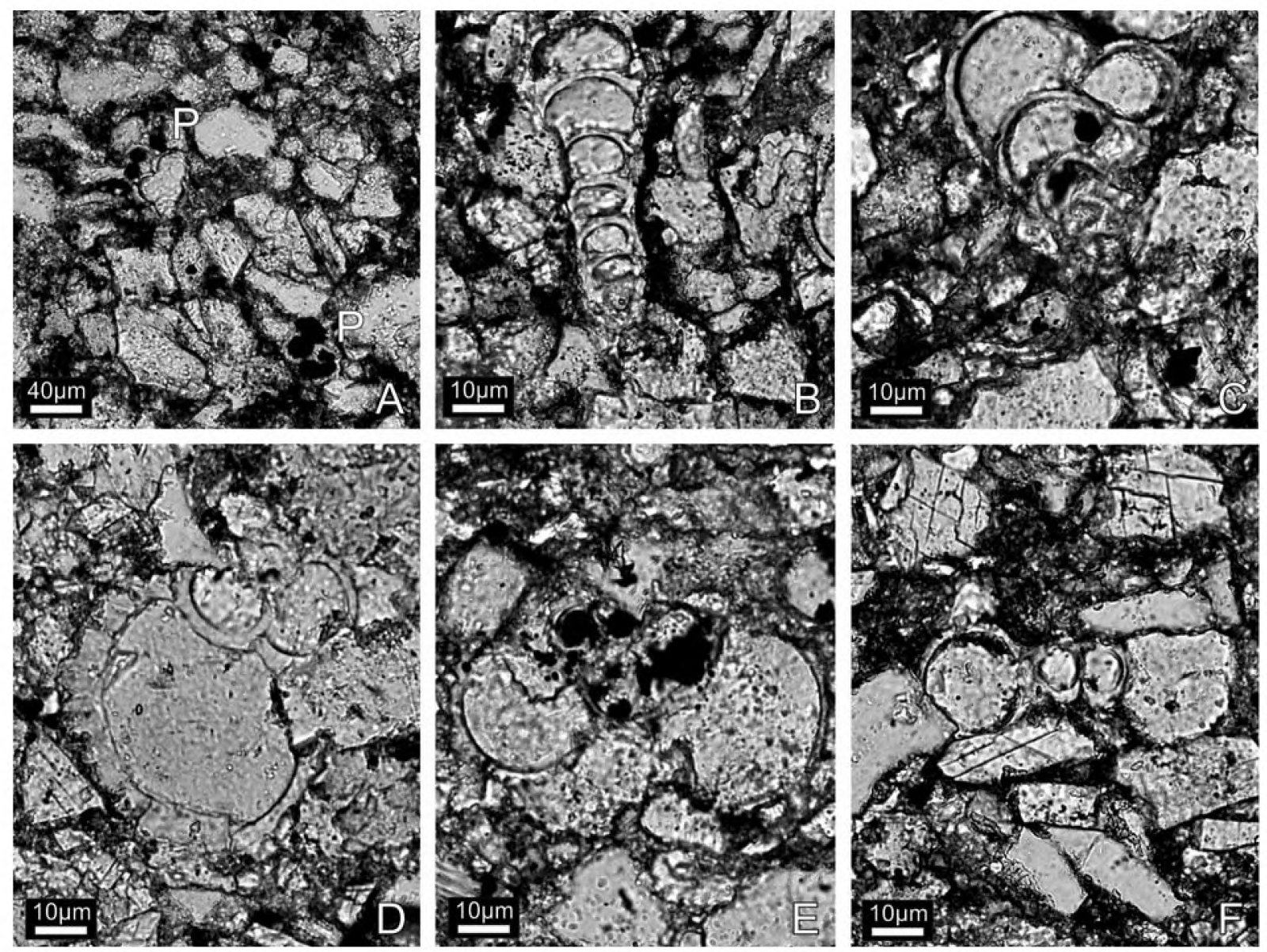

Text-fig. 10. Characteristic planktonic foraminifera from the sample of the Wiktor Kuźniar collection (24/2013). A-abundant Chiloguembelina cf. gracillima (Andreae) (P); B, C-Chiloguembelina cf. gracillima (Andreae); D - Globigerinatheka cf. index (Finlay); E, F - planktonic foraminifera 
ranges from the Jurassic to Recent (Kelly and Bromley 1984). It is worth mentioning that the supposed palm fruits Phoenix szaferi described by Bąkowski (1967) from the Zakopane Beds, which overlie the study deposits, appeared to be Teredolites (Radwański 2009).

Small cylindrical burrows

(Text-fig. 9E)

\section{MATERIAL: 32/2013.}

DESCRIPTION: This trace fossil is preserved as a thin, almost straight ridge, $0.5 \mathrm{~mm}$ wide, running on the surface of the leaf blade of an incertae sedis dicotyledonous leaf and plunging into the surrounding sediments, where its visibility decreases greatly in a short distance from the leaf edge.

REMARKS: This is a burrow produced by unknown, small invertebrate. It resembles the category of "leaf underminings" being small burrows produced preferentially under leaves for food and protection (for sim- ilar interpretation in fresh-water sediments see Uchman et al. 2004) and preserved preferentially as the leaf blade forms a stable "wall" preventing against rapid collapse in normal softground conditions.

\section{RESULTS OF THE REVISION}

The results of the revision are summarised in Tables 1 through 3 .

\section{FORAMINIFERA}

Due to the validity of the Kuźniar collection only two thin sections were prepared from a part of a single rock sample (24/2013). Micropalaeontological analysis of the sections revealed foraminiferal assemblages dominated by planktonic species (Text-fig. 10). Tests of benthic symbiont-bearing taxa belonging mainly to the Nummulitidae occur sporadically and are usually damaged. Some small benthic calcareous forms can also occur.

\begin{tabular}{|l|l|}
\hline \multicolumn{1}{|c|}{ Original name in Kuźniar (1910) } & \multicolumn{1}{c|}{ Current name } \\
\hline Amygdalus pereger Unger & specimen or original label missing \\
\hline Apocynophyllum lanceolatum Unger & Dicotylophyllum sp. 6 \\
\hline Carpinus grandis Unger & $\begin{array}{l}\text { Eotrigonobalanus furcinervis (Rossmässler) Walther et Z. Kv aček ssp. } \\
\text { furcinervis }\end{array}$ \\
\hline Daphnogene melastomacea Unger & ef. Daphnogene sp. \\
\hline Daphnogene melastomacea Unger & Dicotyledones incertae sedis \\
\hline Daphnogene paradisiaca Unger & specimen or original label missing \\
\hline Dryandroides angustifolia Unger & specimen or original label missing \\
\hline Eucaliptus oceanica Unger & Dicotylophyllum sp. 1 \\
\hline Ficus morloti Unger & Dicotyledones incertae sedis \\
\hline Laurus lalages Unger & Dicotyledones incertae sedis \\
\hline Nipadites burtini Brongniart & Nypa burtini (Brongniart) Ettingshausen \\
\hline Poacites sp. & Incertae sedis \\
\hline Podocarpus eocenica Unger & specimen or original label missing \\
\hline Populus mutabilis repando-crenata Heer & Dicotylophyllum sp. 4 \\
\hline Pyrus troglodytarum Unger & Dicotylophyllum sp. 5 \\
\hline Quercus sp. & Incertae sedis \\
\hline Quercus urophylla Unger & specimen or original label missing \\
\hline Sapotacites sideroxyloides Ettingshausen & specimen or original label missing \\
\hline
\end{tabular}

Table 1. Taxonomic determinations of plant remains from the Hruby Regiel section in Kuźniar (1910) and present determinations

\begin{tabular}{|l|l|}
\hline Original name & Current name \\
\hline Edocarpus eocenica Unger & Dicotylophyllum sp. 1 \\
\hline Quercus chlorophylla Unger & Dicotyledones incertae sedis \\
\hline Quercus daena Heer & Dicotylophyllum sp. 3 \\
\hline
\end{tabular}

Table 2. Labelled specimens found in collection of plant remains from the Hruby Regiel section, not mentioned in Kuźniar (1910) and their current taxonomical determinations 


\begin{tabular}{|c|c|c|c|}
\hline $\begin{array}{l}\text { Current } \\
\text { number }\end{array}$ & $\begin{array}{l}\text { Number used by Museum of the } \\
\text { Institute of Geological Sciences, PAS, } \\
\text { Kraków }\end{array}$ & Original name in Kuźniar (1910) & Current name \\
\hline $1 / 2013$ & & & Incertae sedis \\
\hline $2 / 2013$ & & & $\begin{array}{l}\text { cf. Eotrigonobalanus furcinervis } \\
\text { (Rossmässler) Walther et Z. Kvaček }\end{array}$ \\
\hline $3 / 2013$ & & Quercus sp. & Incertae sedis \\
\hline $4 / 2013$ & A-III-61/27 & Poacites sp. & Incertae sedis \\
\hline $4 / 2013$ & A-III-61/24 & & Incertae sedis \\
\hline $5 / 2013$ & & & Dicotyledones incertae sedis \\
\hline 6/2013 & A-III-61/32 & & Dicotylophyllum sp. 1 \\
\hline $7 / 2013$ & A-III-61/17 & & $\begin{array}{l}\text { Eotrigonobalanus furcinervis (Rossmässler) } \\
\text { Walther et } Z \text {. Kvačk ssp. furcinervis }\end{array}$ \\
\hline $8 / 2013$ & A-III-61/5 & Daphnogene melastomacea Unger & cf. Daphnogene sp. \\
\hline $9 / 2013$ & & & Incertae sedis \\
\hline $10 / 2013$ & & & ?Gyrolithes isp. \\
\hline $11 / 2013$ & A-III-61/24 & Eucaliptus oceanica Unger & Dicotylophyllum sp. 1 \\
\hline $12 / 2013$ & A-III-61/20 & & Incertae sedis \\
\hline $13 / 2013$ & & & Ophiomorpha isp. \\
\hline $14 / 2013$ & & & Teredolites clavatus \\
\hline $15 / 2013$ & A-III-61/34 & Nipadites burtini Brongniart & Nypa burtini (Brongniart) Ettingshausen \\
\hline $16 / 2013$ & & & Incertae sedis \\
\hline $17 / 2013$ & A-III-61/26 & & Dicotyledones incertae sedis \\
\hline $18 / 2013$ & A-III-61/21 & & Dicotylophyllum sp. 2 \\
\hline $19 / 2013$ & A-III-61/6 & & $\begin{array}{l}\text { Eotrigonobalanus furcinervis (Rossmässler) } \\
\text { Walther et } Z \text {. Kvacek ssp. furcinervis }\end{array}$ \\
\hline $20 / 2013$ & A-III-61/8 & & Dicotyledones incertae sedis \\
\hline $21 / 2013$ & & & Dicotyledones incertae sedis \\
\hline $22 / 2013$ & & & Dicotyledones incertae sedis \\
\hline $23 / 2013$ & & & Incertae sedis \\
\hline $24 / 2013$ & & & Dicotyledones incertae sedis \\
\hline $25 / 2013$ & A-III-61/19 & & Dicotyledones incertae sedis \\
\hline $26 / 2013$ & A-III-61/28 & Laurus lalages Unger & Dicotyledones incertae sedis \\
\hline $27 / 2013$ & A-III-61/25 & & Dicotylophyllum sp. 3 \\
\hline $28 / 2013$ & & Laurus lalages Unger & Dicotyledones incertae sedis \\
\hline $29 / 2013$ & & & Incertae sedis \\
\hline $30 / 2013$ & A-III-61/10 & Daphnogene melastomacea Unger & Dicotyledones incertae sedis \\
\hline $31 / 2013$ & A-III-61/9 & & Dicotyledones incertae sedis \\
\hline $32 / 2013$ & A-III-61/13 & & Dicotyledones incertae sedis + trace fossil \\
\hline $33 / 2013$ & A-III-61/30 & Populus mutabilis repando-crenata Heer & Dicotylophyllum sp. 4 \\
\hline $34 / 2013$ & A-III-61/14 & & Dicotylophyllum sp. 4 \\
\hline $35 / 2013$ & A-III-61/1 & Ficus morloti Unger & Dicotyledones incertae sedis \\
\hline $36 / 2013$ & A-III-61/33 & Apocynophyllum lanceolatum Unger & Dicotylophyllum sp. 6 \\
\hline $37 / 2013$ & & & Incertae sedis \\
\hline $38 / 2013$ & A-III-61/3 & Nipadites burtini Brongniart & Nypa burtini (Brongniart) Ettingshausen \\
\hline $39 / 2013$ & & & Incertae sedis \\
\hline $40 / 2013$ & A-III-61/7 & & Dicotyledones incertae sedis \\
\hline $41 / 2013$ & A-III-61/12 & & Dicotyledones incertae sedis \\
\hline $42 / 2013$ & A-III-61/29 & Carpinus grandis Unger & $\begin{array}{l}\text { Eotrigonobalanus furcinervis (Rossmässler) } \\
\text { Walther et Z. Kvaček ssp. furcinervis }\end{array}$ \\
\hline $43 / 2013$ & A-III-61/11 & & Dicotyledones incertae sedis \\
\hline $44 / 2013$ & A-III-61/2 & & Dicotyledones incertae sedis \\
\hline $45 / 2013$ & & & Dicotylophyllum sp. 4 \\
\hline $46 / 2013$ & & & Incertae sedis \\
\hline $47 / 2013$ & A-III-61/31 & Pyrus troglodytarum Unger & Dicotylophyllum sp. 5 \\
\hline $48 / 2013$ & A-III-61/18 & & $\begin{array}{l}\text { Dicotylophyllum cf. juglandoides } \\
\text { (Rossmässler) Knobloch et Z. Kvarek }\end{array}$ \\
\hline $49 / 2013$ & A-III-61/15 & & Incertae sedis \\
\hline $50 / 2013$ & A-III-61/22 & & Incertae sedis \\
\hline
\end{tabular}




\section{BIOSTRATIGRAPHIC POSITION OF PLANT- BEARING DEPOSITS}

The biostratigraphical determinations of the source of the plant-bearing deposits are based on the flora and foraminifera. Eotrigonobalanus furcinervis and Nypa burtini are typical plants of the European Palaeogene; $N$. burtini is restricted to the Eocene, disappearing by the end of this epoch (Gee 1990, 2001), whereas E. furcinervis is usually found in the Palaeogene, surviving in some localities until the Early Miocene (Denk et al. 2012).

The abundant planktonic foraminifera are dominated by Chiloguembelina $\mathrm{cf}$. gracillima (Andreae) (Text-fig. 10A-C). This species indicates the standard planktonic foraminifer zones P16/17-P18, dated as latest Priabonian (Late Eocene) through to Rupelian (Early Oligocene) (see Berggren et al. 1995). Similarly, Samuel and Salaj (1968) noted Ch. gracillima in the uppermost part of the Eocene in the Slovak Carpathians. In addition, Olszewska (2009) reported this species from the Priabonian nummulitic deposits of the Tatra Mountains (localities Dolina Lejowa, Żleb Jaroniec, Dolina za Bramką, Suchy Żleb).

The foraminiferal assemblage also contains abundant, exclusively Late Eocene planktonic foraminifera, such as Globigerinatheca cf. index (Finlay) (Text-fig. 10D), and small benthic taxa, such as Eponides cf. poligonus of a Bartonian age and the Priabonian Maslinella champani Glaessner et Wade (Loeblich and Tappan 1988). The assemblage also includes rare, poorly preserved larger benthic foraminifera but they do not allow a precise dating of these deposits. However, the youngest Nummulitidae from the Tatric Eocene are dated as Priabonian (Bieda 1963; Machaniec et al. 2009; Jach and Machaniec 2014), more precisely to the SBZ 19-20 zones (see Serra-Kiel 1997). The co-occurrence of some planktonic (Text-fig. $10 \mathrm{E}, \mathrm{F}$ ) and benthic forms of different ages suggests that the plantbearing deposits may contain some recycled material.

The co-occurrence of Chiloguembelina $\mathrm{cf}$. gracillima and other planktonic and benthic foraminifera (with ranges exclusively up to the Late Eocene) together with well preserved Eocene leaves and fruits limits the age of the plant-bearing deposits to the latest Priabonian.

\section{CHARACTERISTICS OF THE SEDIMENTARY ORGANIC MATTER}

The organic particles in two samples from the plant-bearing deposits from the Hruby Regiel section include no structured organic matter (SOM), i.e. palynomorphs (plant sporomorphs, phytoplankton and zoomorphs) or structured phytoclasts (cuticles, wood tissues; Text-fig. 11A, B). Instead, highly homogeneous opaque and translucent phytoclasts with an admixture of amorphous organic matter (AOM) particles dominate. The AOM consists of both structureless grey fragments (derived from phytoplankton or degradation products of bacteria) and highly degraded plant tissues. The opaque phytoclasts are usually more or less equidimensional (O-Eq), angular, rarely roundish. Some of them are slightly translucent. They represent coalified or highly gelified structureless plant tissues corresponding to the vitrinite or inertinite maceral group. The sample dominated by coalified phytoclasts also contains roundish particles, most probably representing pyrite framboids. The presence of pyrite framboids was confirmed by means of the heavy liquid palynological procedure. After heavy liquid separation of the palynological matter from the residue, the roundish particles sank completely, confirming that they were heavier than the palynological matter, which is typical of pyrite. Pyrite framboids show a broad range of sizes (from $\sim 2 \mu \mathrm{m}$ to $30 \mu \mathrm{m}$ ) with mean diameters exceeding $5 \mu \mathrm{m}$. These framboid characters are typical of upper dysoxic depositional conditions (Wilkin et al. 1996; Bond et al. 2004; Zatoń et al. 2008) and indicate a possible dysoxic sedimentary environment during the deposition of the sediments of the Hruby Regiel section but not necessarily on the sea floor, as suggested by the absence of primary lamination and the occurrence of trace fossils. The absence of structured organic matter (palynomorphs and structured phytoclasts) could be due to a high rate of alteration of organic particles before and/or after burial in sediment. As a result, the palynomorphs and structured phytoclasts were highly degraded, homogenised and also coalified. This is confirmed by the dominance of highly gelified or coalified particles of plant origin.

\section{PALAEOCLIMATIC CONSIDERATIONS BASED ON THE PLANT REMAINS AND FORAMINIFERA}

Generally, there are two approaches to palaeoclimatic reconstructions using fossil leaf floras. The first one is the Nearest Living Relative method (NLR), based on an assumption that climatic tolerances of living relatives are similar to those of the fossil taxa (Mosbrugger and Utescher 1997). The quantitative method using NLR is the coexistence approach (CoA) as proposed by Mosbrugger and Utescher (1997). It 


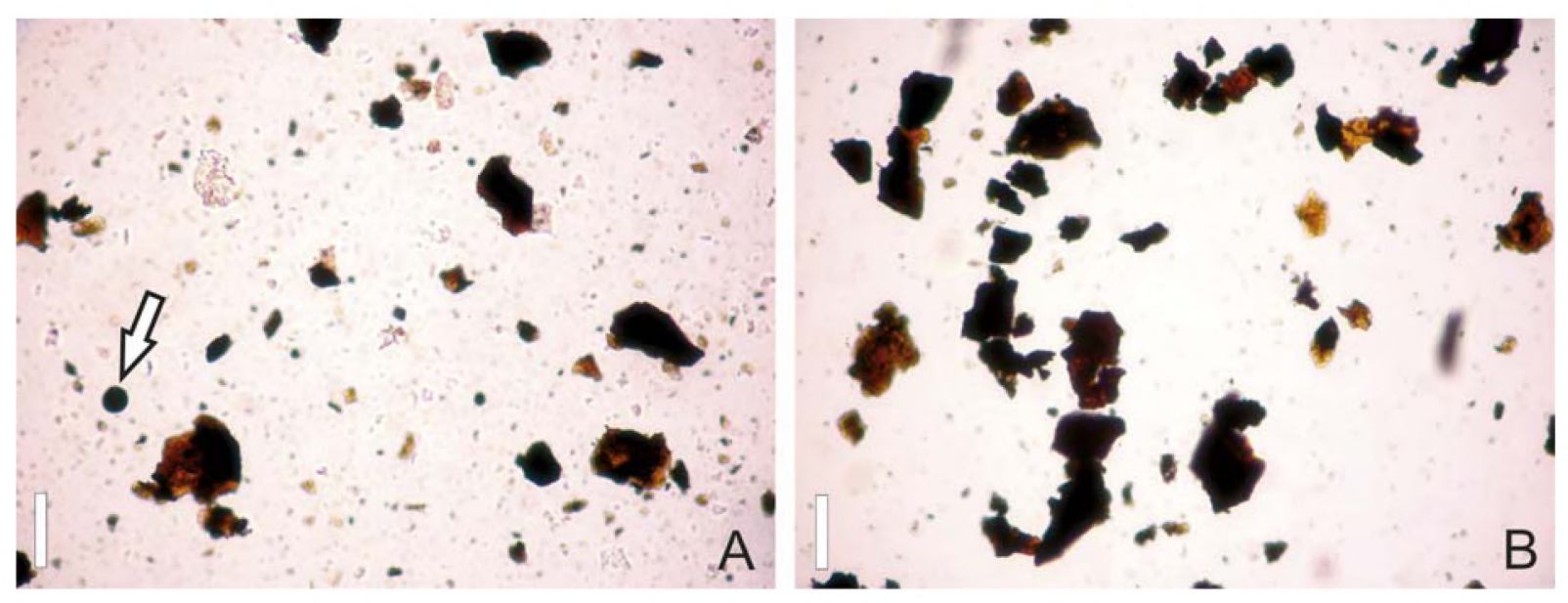

Text-fig. 11. Sedimentary organic matter from Hruby Regiel. Palynofacies dominated by highly homogeneous opaque and translucent phytoclasts. A - sample prepared without heavy liquid separation. Arrow indicates roundish pyrite framboid; B - sample prepared with heavy liquid separation. Visible concentrated SOM. Pyrite framboids completely absent. Scale bar $-50 \mu \mathrm{m}$

can be reliably used only for very young fossil plant assemblages, not older than Palaeogene. The second approach is based on correlation between climate and leaf physiognomy, i.e. the assumption that plant architecture (morphology of leaves) is modified by environmental conditions. Morphological characters used in this method include leaf margin architecture, size and shape of leaf, leaf thickness and the presence of special features, e.g. the drip tips (Spicer 1990). There are two methods for obtaining palaeoclimate proxies from leaf architecture: Leaf Margin Analysis (LMA) and the Climate Leaf Analysis Multivariate Program (CLAMP) using Canonical Correspondence Analysis (Bailey and Sinnott 1915, 1916; Wolfe 1971, 1978, 1993; Wing and Greenwood 1993). Compared with the NLR method, a palaeoclimatic approach based on leaf architecture has no time constraint and can be extended down to the Cretaceous extinct genera. Unfortunately, in the case of the leaf assemblage from the Hruby Regiel section, due to the rather small number of specimens (well below 100), a quantitative application of both NRL and leaf physiognomy methods (LMA + CLAMP) is not credible. Nonetheless, some considerations based on both approaches can be drawn.

Although the systematic position of most of the Eocene plant fossils from the Hruby Regiel section remains unclear, the leaves of Eotrigonobalanus furcinervis and Daphnogene sp. (Lauraceae) and the fruits of Nypa burtini could be related to extant nearest relatives. Eotrigonobalanus furcinervis is related to Recent members of the family Fagaceae belonging to the genera Castanopsis, Lithocarpus and Trigonobalanus (Denk et al. 2012). All of these three genera are restricted to areas of tropical to subtropical climate.
Daphnogene sp. shares morphological characters with at least eleven genera of the Lauraceae with acrodromous venation (Bannister et al. 2012). Like all members of the Lauraceae, these genera prefer warm climatic conditions. Nypa fruticans, a Recent relative of Nypa burtini, grows mostly in a tropical frost-free climate in mangrove communities of southeast Asia (Krutzsch 1989). It grows in areas with a warm and humid climate with a minimum temperature $20^{\circ} \mathrm{C}$ and more than $1,000 \mathrm{~mm}$ annual rainfall evenly distributed throughout the year ( $\operatorname{Lim} 2012)$. N. fruticans is limited to tropical sea coasts with water temperatures above $20^{\circ} \mathrm{C}$ (Fechner 1988; Akgün 2013).

Among foraminifers occurring in the plant-bearing deposits the small, planktonic biserial forms of Chiloguembelina sp. predominate. Symbiont-bearing large benthic foraminifera, represented mainly by Nummulitidae, also occur. Most of their tests show evidence of damage. Large benthic foraminifera are limited to shallow, clear, oligotrophic, warm waters, with temperatures above $20^{\circ} \mathrm{C}$ in the photic zone (e.g. Hohenegger 2004). Planktonic chiloguembelinids required eutrophic water and are restricted to near-coastal environments (D'haenens et al. 2012). In the eutrophic waters of the depositional area, living conditions for large benthic foraminifera were unfavourable. In view of this and the damaged tests of the Nummulitidae, it is possible that the large foraminifera were redeposited from the shallower areas.

The occurrence of the fruits of NyPa in the deposits suggests proximity to the shoreline. Extant $N$. fruticans thrives only in brackish waters, rarely growing directly on the seashore, and is usually found in estuarine tidal floodplains (CABI 2014). It prefers fine-grained sub- 
strates and avoids shores exposed to wave action and hypersaline conditions (Badve and Sakurkar 2003; Ellison et al. 2010; Lim 2012). The occurrence of Nypa, which is limited to coastlines with water temperatures above $20^{\circ} \mathrm{C}$, suggests that the absence of large benthic foraminifers is not conditioned by temperature. It is probable that the increased supply of organic matter, clay minerals (marls) and detrital grains by river(s) were the main limiting factors. Consequently, it can be concluded that during the latest Eocene in the area of the Hruby Regiel section, a warm, subtropical to tropical climate prevailed on the adjacent lands.

Irrespective of the rather limited number (50) of specimens, some deductions in relation to the physiognomy of the studied Eocene leaves can be drawn. Almost all of the taxa, except for E. furcinervis, have leaves with an entire, rarely revolute margin, often with a coriaceous leaf blade. Some leaves are relatively large. These physiognomic characters are typical of extant plants in a subtropical to tropical humid climate (Bailey and Sinnott 1915; Wing and Greenwood 1993; Wiemann et al. 1998; Royer et al. 2005).

In conclusion, the nearest living relatives and the morphological characters of the studied fossil leaf taxa point to a warm and humid climate in the Western Carpathians during the latest Eocene.

\section{PLANT PALAEOCOMMUNITIES}

The Late Eocene in Europe is characterised by transitional changes in vegetation associated with climate cooling. Late Palaeocene to Middle Eocene paratropical evergreen forest vegetation changed stepwise to a broad-leaved, mixed, deciduous and evergreen forest in the Late Eocene, and then to a mixed mesophytic forest in the Oligocene (Collinson and Hooker 2003). The plant assemblage from the Hruby Regiel section represents vegetation similar to the paratropical or subtropical evergreen forests rather than to the broadleaved mixed deciduous forests. Eotrigonobalanus furcinervis, Lauraceae, and numerous leaf remains of entire-margined, coriaceous taxa are typical of paratropical or subtropical evergreen forests. In the Late Eocene of Central Europe, similar vegetation existed in the Atlantic-Boreal, Western and Central Europe Bioprovince (Mai 1995) and is represented by floras of the Hordle-Zeitz Florenkomplex (floral assemblages sensu Mai and Walther 1978). The plant assemblages studied herein are most similar to those from the Staré Sedlo Formation in the Czech Republic (Knobloch et al. 1996; Kvaček and Walther 2003) and in the Weisselster Basin in Germany (Kunzmann and Walther
2002), which represent subtropical evergreen laurophyllous rainforest of a Eotrigonobalanus-QuercusLauraceae association dominated by members of the Fagaceae, Lauraceae, Magnoliaceae, Altingiaceae, Theaceae, Moraceae, Mastixiaceae, Myrsinaceae, Myrtaceae, Olacaceae, Sapindaceae, Saururaceae, Sterculiaceae and Symplocaceae (Mai 1995). Depending on the methods used, the mean annual temperature estimated for Staré Sedlo ranges between 16 and $24^{\circ} \mathrm{C}$ (Uhl et al. 2007). Kvaček (2010) classified this type of Eocene intrazonal vegetation as a broadleaved evergreen riparian gallery forest with palms. The evergreen broad-leaved forests of southeast Asia (Box et al. 1991) may be regarded as its Recent counterpart. The Late Palaeocene and Eocene vegetation of Europe is also characterised by mangroves, which in the material studied are represented by fossil fruits of Nypa burtini. In the European Eocene, thermophilic and humid mangroves were associated with coastlines (Collinson and Hooker 2003). Therefore, the deposits studied accumulated in the proximity of the coast.

\section{TAPHONOMY OF THE PLANT REMAINS}

The plant macroremains are dispersed in finegrained deposits. The flora is allochthonous, as indicated by the mixture of taxa characteristic of mangrove and mesophytic vegetation. The usually good state of preservation of leaves suggests a proximity to the source vegetation. However, most of the leaves are coriaceous. Therefore, they could survive some transportation in a marine environment. The fruits of Nypa could have been transported from more distant coasts.

\section{CONCLUSIONS}

The Kuźniar collection of macroflora from the Hruby Regiel section comprises 50 specimens of plant remains (mainly leaves, but also fruits of $\mathrm{Nypa}$ and some undetermined remains of plant bodies) and a few trace fossils. Both the flora and the foraminiferal assemblages are dated as latest Eocene. The plant assemblage represents paratropical or subtropical evergreen forests in a warm and humid subtropical climate. The occurrence of plants typical of mangroves is indicative of proximity to a shoreline.

Sedimentary organic particles from the Hruby Regiel section do not include any structured organic matter (SOM) such as palynomorphs and structured phytoclasts. A single sample dominated by coalified 
phytoclasts also contains pyrite framboids showing characters indicating a possible dysoxic sedimentary environment during deposition of the sediments of the Hruby Regiel section but not necessarily on the sea floor, as suggested by the absence of primary lamination and the occurrence of trace fossils.

\section{Acknowledgements}

We are grateful to Barbara Kietlińska-Michalik (Museum of the Institute of Geological Sciences, Polish Academy of Sciences, Kraków), who found several specimens from the collection that were dispersed in the storage room. She also organized new cataloguing of the specimens. The research was supported by the Ministry of Sciences and Higher Education 0529/B/P01/2007/33. Additional support was provided by the Jagiellonian University (DS funds). Investigations on plant remains were financed by the W. Szafer Institute of Botany, Polish Academy of Sciences in Kraków through its statutory funds. The authorities of the Polish Tatra National Park (TPN, Zakopane) provided permission for the fieldwork, for which the authors are very grateful. Vlasta Ćosović (University of Zagreb, Croatia) and Ewa Malata (Jagiellonian University, Kraków) are thanked for constructive comments. The manuscript was greatly improved with the help of comments made by Professor Ewa ZastawniakBirkenmajer and an anonymous reviewer.

\section{REFERENCES}

Akgün, F., Akkiraz, M.S., Üçbaş, S.D. Bozcu, M., Kapan Yeşilyurt, S. and Bozcu, A. 2013. Oligocene vegetation and climate characteristics in north-west Turkey: data from the south western part of the Thrace Basin. Turkish Journal of Earth Sciences, 22, 277-303.

APG III [Bremer, B., Bremer, K., Chase, M.W., Fay, M.F., Reveal, J.L., Soltis, D.E., Soltis, P.S. and Stevens, P.F. (comp.)]. 2009. An update of the Angiosperm Phylogeny Group classification for the orders and families of flowering plants: APG III. Botanical Journal of the Linnean Society of London, 161, 105-121.

Bac-Moszaszwili, M., Burchart, J., Głazek, J., Iwanow, A., Jaroszewski, W., Kotański, Z., Lefeld, J., Mastella, L., Ozimkowski, W., Roniewicz, P., Skupiński, A. and Westwalewicz-Mogilska, E. 1979. Geological Map of the Polish Tatra Mountains 1:30 000. Wydawnictwa Geologiczne; Warszawa.

Badve, R.M. and Sakurkar, C.V. 2003. On the disappearance of palm genus $N y p a$ from the west coast with its present status in the Indian subcontinent. Current Science, 85, $1407-1409$
Bailey, I.W. and Sinnott, E.W. 1915. A botanical index of Cretaceous and Tertiary climates. Science, 41, 831-834.

Bailey, I.W. and Sinnott, E.W. 1916. The climatic distribution of certain types of angiosperm leaves. American Journal of Botany, 3, 24-39.

Bannister, J.M., Conran, J.G. and Lee, D.E. 2012. Lauraceae from rainforest surrounding an early Miocene maar lake, Otago, southern New Zealand. Review of Palaeobotany and Palynology, 178, 13-34.

Bartholdy, J., Bellas, S.M., Ćosović, V., Premec Fuček, V. and Keupp, H. 1999. Process controlling Eocene mid-latitude larger foraminifera accumulations: modelling of the stratigraphic architecture of a fore-arc basin (Podhale Basin, Poland). Geologica Carpathica, 50, 435-448.

Bartholdy, J., Bellas, S.M., Mertmann, D., Machaniec, E. and Manutsoglu, E. 1995. Fazies-Entwicklung und Biostratigraphie einer Sequenz eozäner Sedimente im Steinbruch Pod Capkami, Tatra Gebirge, Polen. Berliner Geowissenschaften Abhandlungen, 16, 409-425.

Batten, D.J. 1996. Palynofacies and palaeoenvironmental interpretation. In: J. Jansonius and D.C. McGregor (Eds), Palynology: principles and applications. American Association of Stratigraphic Palynologists Foundation, Dallas, 3, 1011-1064.

Baucon, A., Bordy, E., Brustur, T., Buatois, L.A., Cunningham, T., De, C., Duffin, C., Falletti, F., Gaillard, C., Hy, B., Hu, L., Jensen, S., Knaust, D., Lockley, M., Lowe, P, Mayor, A., Mayoral, E., Mikuláš, R., Muttoni, G., Neto de Carvalho, C., Pemberton, G.S., Pollard, J., Rindsberg, A.K., Santos, A., Seike, K., Song, H., Turner, S., Uchman, A., Wang, Y., Gong, Y., Zhang, L. and Zhang, W. 2012. A history of ideas in ichnology. In: R.G. Bromley and D. Knaust (Eds), Trace Fossils as Indicators of Sedimentary Environments. Developments in Sedimentology, 64, 3-43.

Bąkowski, Z. 1967. Phoenix Szaferi sp. nov. from the Podhale Region and an outline of the history of the genus Phoenix L. Prace Muzeum Ziemi, 10, 169-213.

Berggren, W.A., Kent, D.V., Swisher C.C.III and Aubry, M.-P. 1995. A revised Cenozoic geochronology and chronostratigraphy. In: W.A. Berggren, D.V. Kent, M.P. Aubry, and J. Hardenbol (Eds), Geochronology, Time Scales and Global Stratigraphic Correlation. Society of Economic Paleontologists and Mineralogist Special Publications, 54, 129-212.

Bieda, F, 1963. Larger foraminifers of the Tatra Eocene. Prace Instytutu Geologicznego, 37, 3-215. [In Polish with English summary]

Bond, D., Wignall, P.B. and Racki, G. 2004. Extent and duration of marine anoxia during the Frasnian-Famennian (Late Devonian) mass extinction in Poland, Germany, Austria and France. Geological Magazine, 141, 173193. 
Boulter, M.C., Spicer, R.A. and Thomas, B.A. 1988. Patterns of plant extinction from some palaeobotanical evidence. In: G.P. Larwood (Ed.), Extinction and survival in the fossil record. Systematics Association Special Volume, 34, 1-36.

Box, E.O., Song, Y C., Miyawaki, A. and Fujiwara, K. 1991. An evergreen broad-leaved forest in transitional eastern China. Bulletin of the Institute of Environmental Science and Technology, Yokohama National University, 17, 63-84.

Brongniart, A.T. 1828. Prodrome d'une histoire des végétaux fossils, pp. 1-121. F.G. Levrault; Paris.

Brongniart, A.T. 1849. Tableau des genres de végétaux fossiles considérés sous le point de vue de leur classification botanique et de leur distribution géologique, pp. 127. L. Martinet; Paris.

CABI, 2014. Nypa fruticans (nipa palm). In: Invasive Species Compendium. Wallingford, UK: CAB International. <www.cabi.org/isc >. Downloaded on 4 June 2014.

Collinson, M.E. and Hooker, J.J. 2003. Paleogene vegetation of Eurasia: framework for mammalian faunas. Deinsea, 10, 41-83.

Dąbrowska, M. and Jurewicz, E. 2013. Character and structural evolution of the Mała Ląka Fault in the Tatra Mts., Carpathians, Poland. Acta Geologica Polonica, 63, 137151.

Denk, T., Grímsson, F. and Zetter, R. 2012. Fagaceae from the early Oligocene of Central Europe: persisting new world and emerging old world biogeographic links. Review of Palaeobotany and Palynology, 169, 7-20.

D'haenens, S., Bornemann, A., Roose, K., Claeys, P., and Speijer, R.P. 2012. Stable isotope paleoecology $\left(\delta^{13} \mathrm{C}\right.$ and $\delta^{18} \mathrm{O}$ ) of early Eocene Zeauvigerina aegyptiaca from the North Atlantic (DSDP Site 401). Journal of Austrian Earth Sciences, 105, 179-188.

Ellis, B., Daly, D.C., Hickey, L.J., Johnson, K.R., Mitchell, J.D., Wilf, P. and Wing, S.L. 2009. Manual of Leaf Architecture, pp. 1-190. Cornell University Press, The New York Botanical Garden Press.

Ellison, J., Koedam, N.E., Wang, Y., Primavera, J., Jin Eong, O., Wan-Hong Yong, J. and Ngoc Nam, V. 2010. Nypa fruticans. In: IUCN 2014. IUCN Red List of Threatened Species. Version 2014.1. <www.iucnredlist.org>. Downloaded on 16 June 2014.

El-Soughier, M.I., Mehrotra, R.C., Zhou, Z.Y. and Shi, G.L. 2011. Nypa fruits and seeds from the MaastrichtianDanian sediments of Bir Abu Minqar, South Western Desert, Egypt. Palaeoworld, 20, 75-83.

Ettingshausen, C. 1879. Report on phyto-palaeontological investigations of the fossil flora of Sheppey. Proceedings of the Royal Society of London, 29, 388-396.

Fechner, G.G. 1988. Selected palynomorphs from the Lower to Middle Eocene of the South Atlas border zone (Mo- rocco) and their environmental significance. Palaeogeography, Palaeoclimatology, Palaeoecology, 65, 73-79.

Frey, R.W. and Howard, J.D. 1985. Trace fossils from the Panther Member, Star Point Formation (Upper Cretaceous), Coal Creek Canyon, Utah. Journal of Paleontology, 59, 370-404.

Frey, R.W., Howard, J.D. and Pryor, W.A. 1978. Ophiomorpha: its morphologic, taxonomic, and environmental significance. Palaeogeography, Palaeoclimatology, Palaeoecology, 23, 199-223.

Gee, C.T. 1990 . On the fossil occurrence of the mangrove palm Nypa. In: E. Knobloch and Z. Kvacek (Eds), Proceedings of the Symposium on Paleofloristic and Paleoclimatic Changes in the Cretaceous and Tertiary, Prague, August 28th - September 1st, 1989, pp. 315319. Geological Survey; Prague.

Gee, C. 2001. The mangrove palm Nypa in the geologic past of the New World. Wetlands Ecology and Management, 9, 181-203.

Głazek, J. and Zastawniak, E. 1999. Terrestrial plant fossils in the transgressive Paleogene littoral/flysch sequence of the Tatra Mountains (Central Carpathians). In: L. Stuchlik (Ed.), Proceedings of the $5^{\text {th }}$ EPPC. Acta Palaeobotanica, Supplement, 2, 293-301.

Grabowska, I. 1996a. Flora sporowo-pyłkowa. In: L. Malinowska and M. Piwocki (Eds), Budowa geologiczna Polski 3. Atlas skamienialości przewodnich i charakterystycznych 3a. Kenozoik, trzeciorzęd, paleogen, pp. 395-431. Polska Agencja Ekologiczna; Warszawa.

Grabowska, I. 1996b. Flora liściowa i owocowa. In: L. Malinowska and M. Piwocki (Eds), Budowa geologiczna Polski 3. Atlas skamieniałości przewodnich i charakterystycznych 3a. Kenozoik, trzeciorzęd, paleogen, pp. 432. Polska Agencja Ekologiczna; Warszawa.

Gray, V.R. 1993. Origen y rutas de dispersión de los mangles: una revisión con énfasis en las especies de América. Acta Botanica Mexicana, 25, 1-13.

Guzik, K., Guzik, S. and Sokołowski, S. 1958. Mapa geologiczna Tatr Polskich 1:10 000, arkusz Hruby Regiel A2. Wydawnictwa Geologiczne; Warszawa.

Häntzschel, W. 1934. Schraubenförmige und spiralige Grabgänge in turonen Sandsteinen des Zittauer Gebirges. Senckenbergiana, 16, 313-324.

Hennig, D. and Kunzmann, L. 2013. Taphonomy and vegetational analysis of a late Eocene flora from Schleenhain (Saxony, Germany). Geologia Saxonica, 59, 75-87.

Hohenegger, J. 2004. Depth coenoclines and environmental considerations of Western Pacific larger foraminifera. Journal of Foraminiferal Research, 34, 9-33.

Howard, J.D. and Frey, R.W. 1984. Characteristic trace fossils in nearshore to offshore sequences, Upper Cretaceous of east-central Utah. Canadian Journal of Earth Sciences, 21, 200-219. 
Jach, R., Machaniec, E. and Gradziński, M. 2009. Eocene transgressive deposits in the Polish Tatra Mountains: preliminary results. In: V. Pascucci and S. Andreucci (Eds), 27 th IAS Meeting, 20-23 September 2009 Alghero, Italy, p. 218. Editrice Democratica Sarda; Alghero.

Jach, R., Machaniec, E. and Uchman, A. 2012 (for 2011). The trace fossil Nummipera eocenica from the Eocene nummulitic limestones, Tatra Mts., Poland: morphology and palaeoenvironmental implications. Lethaia, 45, 342-355.

Jach, R. and Machaniec, E,, 2014. Skaly eocenu. In: R. Jach, T. Rychliński, and A. Uchman (Eds), Sedimentary Rocks of the Tatra Mountains, pp. 232-244. Tatrzański Park Narodowy - Wydawnictwa; Zakopane.

Kelly, S.R.A. 1988. Cretaceous wood-boring bivalves from western Antarctica with a review of the Mesozoic Pholadidae. Palaeontology, 31, 341-372.

Kelly, S.R.A. and Bromley, R.G. 1984. Ichnological nomenclature of clavate borings. Palaeontology, 27, 739-807.

Knobloch, E., Konzalová, M. and Kvaček, Z. 1996. Die obereozäne Flora der Staré Sedlo-Schichtenfolge in Böhmen (Mitteleuropa). Rozpravy Českeho Geologickeho Ústavu, 49, 1-260.

Kolakovskii, A.A. 1958. The first addition to the Pliocene flora of Duab. Trudy Sukhumskogo Botanicheskogo Sada, 11, 311-397. [In Russian with English summary]

Kosmowska-Ceranowicz, B. 1996. Flora bursztynu. In: L. Malinowska and M. Piwocki (Eds), Budowa geologiczna Polski 3. Atlas skamienialości przewodnich i charakterystycznych 3a. Kenozoik, trzeciorzęd, paleogen, pp. 433-435.

Krutzsch, W. 1989. Paleogeography and historical phytogeography (paleochorology) in the Neophyticum. Plant systematics and evolution, 162, 5-61.

Kulka, A. 1985. Arni sedimentological model in the Tatra Eocene. Kwartalnik Geologiczny, 29, 31-64.

Kunzmann, L. and Walther, H. 2002. Eine obereozäne Blätterflora aus dem mitteldeutschen Weißelster-Becken. Paläontologische Zeitschrift, 76, 261-282.

Kuźniar, W. 1910. Eocen Tatr i Podhala. I. Sprawozdania Komisyi Fizyograficznej, Akademia Umiejętności, 44, 26-76.

Kvaček, Z. 1971. Fossil Lauraceae in the stratigraphy of the North-Bohemian Tertiary. Sbornik geologickích véd, Paleontologie, 13, 47-86.

Kvaček, Z. 2010. Forest flora and vegetation of the European early Palaeogene - a review. Bulletin of Geosciences, $\mathbf{8 5}$, 3-16.

Kvaček, Z. and Knobloch, E. 1967. Zur Nomenklatur der Gattung Daphnogene Ung. und die neue Art Daphnogene pannonica sp. n. Věstník Ústředního Ústavu Geologického 41, 291-294.
Kvaček, Z. and Walther, H. 1989. Revision der mitteleuropäischen tertiären Fagaceen nach blattepidermalen Charakteristiken III. Teil: Dryophyllum Debey ex Saporta und Eotrigonobalanus Walther \& Kvaček gen. nov. Feddes Repertorium, 100, 575-601.

Kvaček, Z. and Walther, H. 2003. Reconstruction of vegetation and landscape development during the volcanic activity in the České středohoří Mountains. Geolines, Hibsch Special Volume, 15, 60-64.

Lim, T.K. 2012. Nypa fruticans. In: Edible Medicinal and Non-Medicinal Plants. Vol. 1. Fruits, pp. 402-406. Springer; Netherlands.

Loeblich, A.R. and Tappan, H. 1988. Foraminiferal Genera and their Classification, pp. 1-970. Van Nostrand Reinhold Company; New York.

Ludwiniak, M. 2010. Multi-stage development of the joint network in the flysch rocks of western Podhale (Inner Western Carpathians, Poland). Acta Geologica Polonica, 60, 283-316.

Machaniec, E., Jach, R., Gradziński, M., Roniewicz, P. and Uchman, A. 2009. Eocen tatrzański. In: A. Uchman and J. Chowaniec (Eds), LXXIX Zjazd Naukowy Polskiego Towarzystwa Geologicznego, Bukowina Tatrzańska, 2730 września 2009 r., pp. 159-168. Materialy konferencyjne. Państwowy Instytut Geologiczny; Warszawa. [In Polish]

Machaniec, E., Jach, R. and Gradziński, M. 2011. Morphotype variation of orthophragminids as a paleoecological indicator: A case study of Late Bartonian limestone, Pod Capkami Quarry, Tatra Mts, Poland. Annales Societatis Geologorum Poloniae, 81, 199-205.

Mai, D.H., 1976. Fossile Früchte und Samen aus dem Mitteleozän des Geiseltales. Abhandlungen des Zentralen Geologischen Instituts, 26, 93-149.

Mai, D.H. 1995. Tertiäre Vegetationsgeschichte Europas, pp. 1-691. Gustav Fischer Verlag; Jena, Stuttgart, New York.

Mai, D.H. and Walther, H. 1978. Die Floren der Haselbacher Serie im Weißelster-Becken (Bezirk Leipzig) DDR. Abhandlungen des Staatlichen Museums für Mineralogie und Geologie zu Dresden 28, 1-200.

Mai, D.H. and Walther, H. 2000. Die Fundstellen eozaner Floren des Weisselster-Beckens und seiner Randgebiete. Altenburger Naturwissenschaftiche Forschungen, 13, 159.

Mansfield, C. 1927. Some peculiar fossils from Maryland. Proceedings of the United States National Museum, 71, 1-9.

Mayoral, E. and Muniz, F. 1998. Nuevos datos icnotaxonomicos sobre Gyrolithes del Plioceno inferior de la Cuenca del Guadalquivir (Lepe, Huelva, España). Revista Española de Paleontologia, 13, 61-69.

Mikuláš, R. and Pek, I. 1994. Spirocircus cycloides, a new ich- 
nofossil from the Upper Cretaceous in northern Moravia. Věstník Českého Geologickéo Ústavu, 69, 75-77.

Moore, P.D., Webb, J.A. and Collinson, M.E. 1991. Pollen Analysis, 216 pp. Blackwell; Oxford.

Mosbrugger, V. and Utescher, T. 1997. The coexistence approach - a method for quantitative reconstructions of Tertiary terrestrial palaeoclimate data using plant fossils. Palaeogeography, Palaeoclimatology, Palaeoecology, 134, 61-86.

Netto, R.G., Buatois, L.A., Mángano, M.G. and Balisteri, P. 2007. Gyrolithes as a multipurpose burrow: an ethological approach. Revista Brasileira de Paleontologia, 10, 157-168.

Olszewska, B. 2009. Small foraminifera of "Nummulitic Eocene" of the Tatra Mts. - stratigraphical aspect and paleoenvironment. Przeglad Geologiczny, 57, 703-713. [In Polish with English summary]

Olszewska, B.W. and Wieczorek, J. 1998. The Paleogene of the Podhale Basin (Polish Inner Carpathians) - micropaleontological perspective. Przeglad Geologiczny, 46, 721728.

Passendorfer, E. 1983. Jak powstaly Tatry, pp. 1-286. Wydawnictwo Geologiczne; Warszawa.

Plaziat, J. C., Cavagnetto, C., Koeniguer, J. C. and Baltzer, F. 2001. History and biogeography of the mangrove ecosystem, based on a critical reassessment of the paleontological record. Wetlands Ecology and Management, 9, 161180.

Prothero, D.R. 1994. The late Eocene-Oligocene extinctions. Annual Review of Earth and Planetary Sciences, 22, 145 165.

Raciborski, M. 1892. Zapiski paleobotaniczne. Paleoceńska flora w Tatrach. Kosmos, 17, 526-533.

Radomski, A. 1959. Podhale flysch sedimentation. Biuletyn Instytutu Geologicznego, 149, 251-257. [In Polish with English summary]

Radwański, A. 2009. 'Phoenix szaferi' (palm fruitbodies) reinterpreted as traces of wood-boring teredinid bivalves from the Lower Oligocene (Rupelian) of the Tatra Mountains, Poland. Acta Palaeobotanica, 49, 279-286.

Reveal, J.L. 1996. Newly required suprageneric names in vascular plants. Phytologia, 79, 68-76.

Röder, H. 1977. Zur Beziehung zwischen Konstruktion und Substrat bei mechanisch bohrenden Bohrmuscheln (Pholadidae, Terenidae). Senckenbergiana Maritima, 9, 105213.

Roniewicz, P. 1969. Sedimentation of the Nummulite Eocene in the Tatra. Acta Geologica Polonica, 19, 503-608.

Rossmässler, E.A. 1840. Die Versteinerungen des Braunkohlensandsteins aus der Gegend von Altsattel in Böhmen (Elnbogener Kreises), pp. 42. Dresden \& Leipzig.

Royer, D.L., Wilf, P., Janesko, D.A., Kowalski, E.A. and
Dilcher, D.L. 2005. Correlations of climate and plant ecology to leaf size and shape: potential proxies for the fossil record. American Journal of Botany, 92, 11411151.

Samuel, O. and Salaj, J. 1968. Microstratigraphy and Foraminifera of the Slovak Carpathian Paleogene, pp. 1332. Geologický ústav Dionýza Štúra; Bratislava.

Sepkoski Jr, J.J. 1996. Patterns of Phanerozoic extinction: a perspective from global data bases. In: O.H. Walliser (Ed.), Global Events and Event Stratigraphy in the Phanerozoic, pp. 35-51. Springer-Verlag; Berlin-Heidelberg.

Serra-Kiel, J., Hottinger, L., Caus, E., Drobne, K., Ferrandez, C., Kumar Jauhri, A., Less, G., Pavlovec, R., Pignatti, J., Samso, J. M., Schaub, H., Sire, E., Strougo, A., Tambareau, Y., Tosquella, Y. and Zakrevskaya, E. 1998. Larger foraminiferal biostratigraphy of the Tethyan Paleocene and Eocene. Bulletin de la Société Géologique de France, 169, 281-299.

Sokolowski, S. 1959. Geological map of the Nummulitic Eocene Region - Northern Margin of the Polish Tatra. Bitletyn Geologiczny, 149, 197-213. [In Polish with English summary]

Spicer, R.A. 1990. Fossils as environmental indicators: climate from plants. In: D.E.G. Briggs and P.R. Crowther (Eds), Paleobiology: A Synthesis. Blackwell Science, Oxford, 401-403.

Starczewska-Koziolowa, A. 1961. Contact of the sub-Tatric series with the Eocene on Krokwia Hill near Zakopane. Kwartalnik Geologiczny, 5, 207-216. [In Polish with English summary]

Szafer, W. 1958. New Eocene flora in the Tatra Mountains: Preliminary information. Kwartalnik Geologiczny, 2, 173176. [In Polish with English summary]

Takhtajan, A. 2009. Flowering Plants, pp. I-XLV, 871. Springer Verlag; Berlin.

Tralau, H. 1964. The genus Nypa van Wurmb. Kungliga Svenska Vetenskapsakademiens. Handlingar. Fjärde serien, $\mathbf{1 0}$, 5-29.

Tsuji, K., Ghazalli, M.N.F. and Ariffin, Z. 2011. Biological and ethnobotanical characteristics of Nipa palm (Nypa fructicans Wurmb.): A review. Sains Malaysiana, 40, 14071412.

Tyson, R.V. 1993. Palynofacies analysis. In: D.G. Jenkins (Ed.), Applied Micropaleontology, pp. 153-191. Kluwer Academic Publishers; Dordrecht.

Tyson, R.V. 1995. Sedimentary Organic Matter. Organic Facies and Palynofacies, pp. 615. Chapman and Hall; London.

Uchman, A. 1995. Taxonomy and palaeoecology of flysch trace fossils: The Marnoso-arenacea Formation and associated facies (Miocene, Northern Apennines, Italy). Beringeria, 15, 1-115. 
Uchman, A. 1998. Taxonomy and ethology of flysch trace fossils: A revision of the Marian Książkiewicz collection and studies of complementary material. Annales Societatis Geologorum Poloniae, 68, 105-218.

Uchman, A. and Hanken, N.-M. 2013. The new trace fossil Gyrolithes lorcaensis isp. $\mathrm{n}$. from the Miocene of SE Spain and a critical review of the Gyrolithes ichnospecies. Stratigraphy and Geological Correlation, 21, 72-84.

Uchman, A., Pika Biolzi, M. and Hochuli, P.A. 2004. Oligocene trace fossils from temporary fluvial plain ponds: an example from the Freshwater Molasse of Switzerland. Eclogae Geologicae Helvetiae, 80, 133-148.

Uhl, D., Klotz, S., Traiser, C., Thiel, C., Utescher, T., Kowalski, E. and Dilcher, D.L. 2007. Cenozoic paleotemperatures and leaf physiognomy - a European perspective. Palaeogeography, Palaeoclimatology, Palaeoecology, 248, 24-31.

Uhl, D., Walther, H. and Krings, M. 2002. The Palaeogene flora of Hochstetten-Dhaun (Nahe-area, Rhineland-Palatinate, SW-Germany). Feddes Repertorium, 113, 477-491.

Wiemann, M.C., Manchester, S.R., Dilcher, D.L., Hinojosa, L.F. and Wheeler, E.A. 1998. Estimation of temperature and precipitation from morphological characters of dicotyledonous leaves. American Journal of Botany, 85, 1796-1802.

Wilde, V. 1995. Die Makroflora aus dem Mitteleozän des Geiseltalgebietes, kurze Übersicht und Vergleiche. Hallesches Jahrbuch für Geowissenschaften, 17, 121138.

Manuscript submitted: $3^{\text {wd }}$ July 2014

Revised version accepted: $20^{\text {th }}$ March 2015
Wilkin, R.T., Barnes, H.L. and Brantley, S.L. 1996. The size distribution of framboidal pyrite in modern sediments: An indicator of redox conditions. Geochimica et Cosmochimica Acta, 60, 3897-3912.

Wing, S.L. and Greenwood, D.R. 1993. Fossils and fossil climate: the case for equable continental interiors in the Eocene. Philosophical Transactions of the Royal Society of London. Series B: Biological Sciences, 341 (1297), 243-252.

Wolfe, J.A. 1971. Tertiary climatic fluctuations and methods of analysis of Tertiary floras. Palaeogeography, Palaeoclimatology, Palaeoecology, 9, 27-57.

Wolfe, J.A. 1978. A paleobotanical interpretation of Tertiary climates in the Northern Hemisphere. American Scientist, 66, 694-703.

Wolfe, J.A. 1993. A method of obtaining climatic parameters from leaf assemblages. U.S. Geological Survey Bulletin, 2040, 1-71.

Worobiec, G. 2007. Laurus abchasica (Kolakovsky \& Shakryl) Ferguson from the Neogene of the Bełchatów Lignite Mine (Central Poland). Acta Paleobotanica, 47, 203-215.

Zachos, J., Pagani, M., Sloan, L., Thomas, E. and Billups, K. 2001. Trends, rhythms, and aberrations in global climate 65 Ma to present. Science, 292, 686-693.

Zatoń, M., Rakociński, M. and Marynowski, L. 2008. Pyrite framboids as paleoenvironmental indicators. Przeglad Geologiczny 56, 158-164. [In Polish with English summary] 